\title{
Göç ve Medeniyet: Osmanlı Afrika'sında (Libya) Medeniyetin İnşasında Göçmenlerin Rolü
}

\author{
Migration and Civilization: \\ The Role of Immigrants in the Construction of Civilization in Ottoman Africa \\ (Libyan)
}

\section{Metin MENEKȘE*}

Öz: Bugün Libya toprakları içerisinde yer alan Trablusgarp ve Bingazi, 1912 yılında imzalanan Uşi Antlaşması'na kadar geçen dört asır boyunca Osmanlı Kuzey Afrika'sının önemli bir bölümünü teşkil etmiştir. Osmanlı Hükümeti, yerel idareden gelen raporlar doğrultusunda hareket ederek birtakım önlemler alma gayreti içerisinde olmuş ve bölgede kalıcı olmak için son ana kadar mücadele vermiştir. Nitekim bölgedeki nüfusu, ekonomiyi, askeri yapıyı güçlendirmek amacıyla yerel idareyle birlikte çeşitli imar ve iskân faaliyetleri yürütülmüştür. Bölgenin aktif hale gelmesi, üretime açılması ve yerli halkın "daire-i medeniyete ithali (medenileşmeleri/uygarlaşmaları)" için özellikle kaybedilen topraklardan gelen göçmenlerin iskânı bir firsat olarak görülmüş ve bu anlamda çalışmalar yapılmıştır. Bu çalışmalar neticesinde de bütün zorlu şartlara ve uyum problemlerine rağmen az sayıda göçmen, bölgede tutunmayı başarmış ve Afrika topraklarında birtakım farklılıkları ortaya çıkarmışlardır. Yaşadıkları bölgenin sosyal, kültürel ve ekonomik hayatına bir canlılık ve yenilik getirmişlerdir. Netice itibariyle bu çalışmada, bölgede göçmen iskânıyla hedeflenen ekonomik kalkınma ve yerli halkın "medenileştirilmesi” konusunda devletin attığı adımların ve sonuçlarının incelenmesine; az sayıda göçmenin, bölgenin sosyal, kültürel ve ekonomik hayatına nasıl etki ettiğinin örnekleriyle ortaya konulmasına çalışılmıştır. Bunu yaparken de arşiv belgeleri, resmi ve süreli yayınlar, hatıratlar ve araştırma eserler kullanılmıştır.

Anahtar sözcükler: Osmanlı Afrika'sı, Trablusgarp ve Bingazi (Libya), Göçmen İskânı, Medeniyet İnşası

\begin{abstract}
Tripoli and Benghazi, which are within the Libyan territories today, constituted an important part of the Ottoman North Africa for four centuries until the Ochy Treaty signed in 1912. The Ottoman State, acting in line with the reports from the local administration, made an effort to take some measures and struggled until the last moment to be permanent in the region. Thus, it carried out various development and settlement activities with the local administration in order to strengthen the population, economy and military structure. In order for the "civilizing" of the local people, the region to become active and open to production, especially the settlement of immigrants from the lost lands was seen as an opportunity and efforts were made in this sense. As a result of these studies, despite all the difficult conditions and adaptation problems, a small number of immigrants managed to hold on to the region and revealed some differences in African soil. They brought a vitality and innovation to the social, cultural and economic life of the region they live in. In conclusion, in this study, it is aimed to examine the steps taken by the state and its results regarding the economic development targeted with the resettlement of immigrants in the region and the "civilizing" of the local people; It has been tried to reveal how a small number of immigrants affect the social, cultural and economic life of the region with examples. While doing this, archive documents, official and periodicals, memoirs and research works were used.
\end{abstract}

Keywords: Ottoman Africa, Tripoli and Benghazi (Libyan), Settlement of Immigrants, Civilization Building

\footnotetext{
* Dr., Muğla Sttk1 Koçman Üniversitesi, Edebiyat Fakültesi, Tarih Bölümü, Muğla. m.menekse@mu.edu.tr. https://orcid.org/0000-0003-1192-3161.
} 
"Uygarlıkların ortaya çıkması ve birbirleriyle etkileşmesi göçler sayesinde olmuştur. Göç olgusunun yaşanmadığ ve tamamen durduğu yerde genellikle statik bir toplum yapısı ortaya çıkmıs ve bu durum toplumun geliş̧mesine çoğu zaman engel teşkil etmişsir" (Ortaylı 2006, 19).

"Göçlerle birlikte farkl fiziki yapılara, dillere, dinlere ve kültürlere sahip insanlar bir araya gelmişler ve etkileşim içinde olmuşlardır. Böylece yeni ırklar, kültürler, idare şekilleri ve yaşam biçimleri ortaya çıkmıştır. Bu yeni şartlar günümüz toplumlarının oluşmasına zemin hazırlamıştır” (Karpat 2010b, 9).

\section{Göç, Medeniyet ve Osmanlı Medeniyeti}

Göç, insanlık tarihiyle özdeş bir olgudur (Yalçın 2004, V). Diğer bir deyişle, insan varlığının ve insanlık tarihinin temel olgularından biridir (Arslan 2001, 149). İlkçağlardan itibaren insanların çeşitli nedenlerle göç ettikleri bilinen bir gerçektir (Yalçın 2004, 96). Göç, sosyal tarihin bütün kesitlerinde görülen bir vakadır. İnsanlık tarihinde göçlerin tamamen durduğu bir dönemden söz edilemez. Sadece hızlandığı-yavaşladığı, göçe yol açan sebeplerden birinin ya da birkaçının diğerlerine nazaran nisbi ağırlık kazandığı dönemlerden söz edilebilir (Arslan 2001, 150).

Göç kavramı ile ilgili farklı tanımlar yapılmıştır. Karpat (2010a, 3), göçü, "asıl yerden, ulaşılmak istenilen yere hareket" olarak tanımlamıştır. Akkayan'a $(1979,20)$ göre, "kişilerin hayatlarının gelecekteki kısmının tamamını veya bir kısmını geçirmek üzere bir iskân ünitesinden diğerine yerleşmek kaydıyla yaptıkları coğrafi bir yer değiştirme olayıdır”. Yalçın'a (2004, 12-13) göre, bir yerden başka bir yere yapılan; sosyokültürel, politik ve bireysel dinamiklerden etkilenen; kısa, orta ve uzun vadeli olabilen; geriye dönüş planlı veya sürekli yerleşim hedefi güden bir yer değiştirme hareketidir. Arslan'a $(2001,149)$ göre, kişinin yeni şartlara daha iyi uyum sağlayabilmek amaciyla ya da doğal, ekonomik, siyasal ve benzeri zorunluluklar neticesinde yaşadığı cemiyeti ve sosyal çevreyi değiştirmesi, bir başka çevreye, yabancısı olduğu bir çevreye ve insan topluluğuna katılması olayıdır. Uluslararası Göç Hukuku'nda (Göç Terimleri Sözlüğü 2009, 22) ise, "Uluslararası bir sınırı geçerek veya bir devlet içinde yer değiştirmek; süresi, yapısı ve nedeni ne olursa olsun insanların yer değiştirdiği nüfus hareketleri” olarak tanımlanmıştır.

Göçü cemiyetteki diğer yer değiştirmelerinden ayıran başlıca ölçü, göç edenin eski sosyal ve ekonomik ilişkilerini değiştirmesi, yeni yerleşim yerinde yeni sosyal ve ekonomik ilişkiler kurmasıdır. Bu sebeple kısa süreli ve mevsimlik yer değiştirmeler göç sayılmamaktadır. Bir yer değiştirmenin göç sayılabilmesi için, süresinin en az bir sene olması gerektiği ileri sürülmektedir (Arslan 2001, 149). Fakat bu süre kimilerine göre bir y1l kimilerine göre daha fazla olarak ifade edilmişse de konuyla ilgili olarak tam bir mutabakata varılamamıştır (Tekeli 1998, 9).

Göçe neden olan faktörlerin çok olması, bu konuda farklı sınıflandırmaların yapılmasını ortaya çıkarmıştır. Bu anlamda Yalçın'ın yapmış olduğu sınıflandırmaya bakıldığında, ilk olarak irade esasına göre göçler yer almaktadır. Bunlar gönüllü ve zorunlu göçler olmak üzere ikiye ayrılır. Gönüllü göçte göç hareketine karar veren bizzat bireyin kendisidir. Zorunlu göçler ise savaş tehlikesi gibi can güvenliğinin söz konusu olduğu, bireylerin yaşamak ya da baskılardan kurtulmak için göç etmekten başka çarelerinin olmadığı durumlarda ortaya çıkan göçlerdir. İkinci sınıflama ise göçün yoğunluğuna göre yapılmaktadır. Bu da kitlesel ve bireysel göçler şeklinde kendini gösterir. Üçüncü sınıflama ise ülke sınırları esasına göredir. $\dot{I}_{c ̧}$ ve $d l s ̧$ göç şeklinde ortaya çıkar. İç göç; bir ülkenin kendi sınırları içinde bölge, kent, kasaba, köy gibi bir yerleşim yerinden başka bir yerleşim yerine doğru hareket etmektir. Dış göçler ise bireylerin birtakım nedenlerle kendi ülkesinden başka bir ülkeye hareket etmesi şeklinde ortaya 
çıkmaktadır. Dördüncü sınıflama ise yerleşme süreleri esasına göre yapılır. Bunlar da geçici göçler ve sürekli yerleşme amacıyla yapılan göçler şeklinde kendini gösterir (Yalçın 2004, 13).

Tekeli'ye göre, insanların büyük kitleler halinde ve gönüllü olmadan yer değiştirmelerinin üç farklı sebebi olabilir. Bunlar; devletin belli amaçlarını gerçekleştirmek, savaşlar sonucunda yeniden uyum sağlama çabaları ve doğal afetlerin sonuçlarından kaçınmak olarak sıralanabilir. İlk iki sebebin devletle ilişkisi olduğu açıktır. Üçüncü sebebin kaynağında devlet olmamasına rağmen çözümü devletten beklenmektedir. Bu sebeple her zaman zorunlu yer değiştirme olgularının bir yanında birey varken diğer yanında devlet vardır (Tekeli 2013, 141).

Osmanlı döneminde Müslümanların gerçekleştirmek zorunda kaldığı göç hareketlerinin başlıca "itici" nedenleri, yaklaşık olarak aynı ve ortaktır. İçerisinde; savaşlar, katliamlar, yağmalar, tecavüzler, bask1 ve ayrımlar, tecritler, sürgünler ve zorla asimilasyonlar yer almaktadır (Dış Türkler (Belgeler) 1969, 645). Bu nedenlerden dolayı Osmanlı toprakları üzerinde ilk göç hareketleri başlamıştır. XVII. yüzyılın sonlarından itibaren her toprak kaybedilişinde, Türkler ve diğer Müslüman gruplar göçe zorlanmıştır. Özellikle Balkanlar âdeta bu grupların sürekli göç dalgalarıyla çalkalanmıştır (Popovic 1995, 186). Netice itibariyle, Osmanlı Devleti'nin girdiği savaşları kaybetmesi ve çeşitli siyasal nedenlerle 1783-1914 yılları arasında Kırım, Kafkasya ve Balkanlar'dan 7.4 milyon insanın göç ettiği tahmin edilmektedir (Karpat 2014, 129; Kırım, Kafkasya ve Balkanlar'dan yaşanan göçlerle ilgili detaylı bilgi için ayrıca bkz. Saydam 2010; Erkan 1996; İpek 1999; Karpat 2010b; McCarthy 2012).

Göçmen kavramına bakıldığında, Osmanlı döneminde buna karşılık kullanılan tabir "muhacir"dir. Meskûn olduğu bölgede değerlerini yaşatamayan ve değerlerini yaşatabileceği yere göç eden kişi anlamına gelmektedir. Düşmandan kaçıp Türk hâkimiyetindeki topraklara sığınan kahırzede ve zulmdide Müslümanlardır. Bu insanlar, ya malını mülkünü terk ile savaş alanından ve düşman mezaliminden kaçanlar, ya da savaş sonrası düşmana terk edilen arazide kalıp ecnebi devletin gizli ve aşikâr zulüm ve istibdadına tahammül edemeyerek Anadolu'ya yerleşmek amacıyla sığınan muhtaç ve aciz kişilerdir (İpek 2014, 16-17). Göç sebeplerine göre göçmenleri; sürgünler, anlaşmalara tabi göçmenler, tahliye olunanlar, milli göçmenler, mülteciler, siyasi mülteciler, geri gelenler, yurtsuzlar, devletsizler ve diğer terimlerle tanımlamak mümkündür (İpek 2006, 17-18).

Meydana gelen kitlesel göç hareketlerinin her ne kadar kendi içinde riskler barındırdığı, zaman zaman da çatışmalara kaynaklık ettiği görülse de göçün dünya tarihine ve medeniyetin gelişmesine sağladığı katkılarının da olduğu bir gerçektir (Kaya ve Erdoğan 2015, 5-6). Medeniyet, belirli bir insan topluluğunun belirli bir coğrafya üzerinde ve belirli bir zaman içindeki manevi varlıklarını, fikir ve sanat çalışmalarıyla ilgili niteliklerini ve değerlerini içeren bir kavramdır. Dolayısıyla ilgili insan topluluğunun yer değiştirmesiyle bu nitelikler ve değerler de onlarla birlikte yer değiştirmekte ve zamanla bu yeni yerdeki sosyal, kültürel ve ekonomik hayatı etkilemektedir. $\mathrm{Bu}$ anlamda göç hareketi, önemli bir rol üstlenmektedir. Göçler neticesinde gelen topluluklar sahip oldukları kültür ve medeniyeti de taşımaktadırlar.

Medeniyet konusuna ayrıca değinmek gerekirse, kavram olarak Arapça'da "şehir" anlamına gelen "medîne" isminden türetilmiştir. Kelime, kök itibariyle "yönetmek" (es-siyase) ve "malik olmak" anlamları da bulunan deyn (dîn) mastarıyla ilişkilidir. Medeni (medeniye) ve medini ise şehre mensup olan, şehirli manasına gelmektedir. Medeniyet kavramı Medine'den esinlenerek türetilmiş olup, şehirliliği, dinin şehirde ekonomik, kültürel, estetik, siyasi anlamda ifadesinin somutlaştığı dünya görüşünün yaşamda ifadesini bulan bütün kastedilmektedir. Kavramın Batı dillerindeki karşılığı "Civilisation"dır. Civilisation, Latince'de "şehirli" anlamına gelen "civilis" kelimesinden türetilmiştir. Osmanlı'nın son devrinde civilisation teriminin Modern 
Batı'nın düşünce sistematiğinde ifade ettiği anlamları karşılamak için “medeniyet” kelimesi Türkçeye kazandırılmıştır (Medeniyet kavramı ile ilgili detaylı bilgi için bkz. Kutluer 1998, 296-297)

Fransa'da ortaya çıktıktan sonra diğer Avrupa dillerine yayılıp bir kavram haline gelen civilisationun Türkiye'deki tarihi Mustafa Reşit Paşa ile başlamış ve kelime kısa sürede medeniyetle karşılanmıştır. Mustafa Reşit Paşa, 1834 yılında Paris’ten gönderdiği resmi yazılarında "sivilizasyon" olarak kullandığı bu kavramın Türkçe karşı1lı̆ını bulamadığ için "terbiye-i nâs ve icrâ-yı nizâmât" olarak tarif etmiştir (Kaynar 1985, 69). Eldeki son verilere göre sözcüğü medeniyet olarak ilk defa Sadık Rıfat Paşa 1838'de kullanmış ve bundan sonra Türkçeye yerleşmiştir (Baykara 1999, 31; Karaçavuş 2015, 89). "Belli yasalara uyarak şehirde yaşayan halk" manasındaki uygurdan türetilen uygarlık kelimesi de günümüz Türkçe'sinde medeniyet karşılığı olarak belli bir yaygınlığa sahiptir (Kutluer 1998, 296). Kültür (Culture) kavramı ise ekip-biçmek, topră̆ iş̧lemek, ziraat yapmak anlamına gelen Latince colere kökünden gelmektedir (Bergen 2012, 40). Kafesoğlu'na göre medeniyet, kültürden farklı bir anlam taşımaktadır: "Medeniyet, milletlerarası ortak değerler seviyesine yükselen anlayış, davranış ve yaşama vasıtaları bütünüdür." Burada söz konusu olan ortak değerlerin kaynağı ise kültürlerdir (Kafesoğlu 1989, 15).

İnsanlık tarihinin bilinen en eski medeniyet havzalarına bakıldığında, Afro-Avrasya ana kıtasının uzun suyolları üzerinde kurulan ve bu bölgelerden çevreye yayılan Mezopotamya, Mısır, Hint, Çin ve Ege/Yunan medeniyet havzaları karşımıza çıkmaktadır. Nehir boylarında kurulan Misır, Mezopotamya, Hint ve Çin medeniyetleri, insanoğlunun varlık, bilgi ve değer problematiklerine dair felsefi problemlerle ilgili ilk düşünce ürünlerinin ve bu düşünce ürünlerinin sosyal, siyasi ve ekonomik düzen haline dönüşme biçimlerinin şekillendiği havzalar olmuştur. Kadim medeniyet havzalarının ve etkileşim bölgelerinin büyük bir kısmını bir siyasi ve ekonomik düzen kurarak ortak bir otorite altında birleştiren eklektik siyasi yapılar ise, dönemlerine göre sınırlı bir küreselleşme etkisi yapmışlardır. Bu yapılar, aynı zamanda, birbirlerinden bağımsız olarak gelişen medeniyet birikimlerinin tanışmalarına, aktarılmalarına ve yüzleşmelerine zemin hazırlamışlardır. Bu siyasi yapılar arasında yer alan özellikle İskender İmparatorluğu, Roma İmparatorluğu, Emevi ve Abbasi devletleri, Moğol hâkimiyeti ve Osmanlı düzeni, kadim birikimin kökleşmesinde, sentezlenmesinde, harmanlanmasında ve yeniden üretilmesinde önemli dönüm noktaları olmuşlardır (Davutoğlu 2012, 7-8).

Osmanlı Devleti, bir taraftan İslam medeniyeti mirasını eksen alarak klasik medeniyet havzalarının tümüne bünyesinde yer veren bir kuşatıcılık sergilerken, diğer yandan dünya ana kıtasının gördüğü en kapsamlı stratejik yönelişlerinden birini gerçekleştirmiştir. Devletin kullandığı semboller, unvanlar, kavramlar ve kurumlar bu kapsayıcılığın izlerini taşımaktadır. Osmanlı sultanları hem Halife (İslam), hem Padişah (İran), hem Hakan (Turan), hem de Kayzer-i Rum'dur. İslam düşünce tarihinin değişik ekolleri Osmanlı kültür atmosferinde uyumlu bir bütünlük oluşturmuş, Eflatun'dan Farabi'ye, İran devlet geleneğinden Roma'ya uzanan siyasi düşünce ve tecrübe birikimi, Osmanlı düzeninde iç uyumu bozmayan bir hayat alanı bulabilmiştir (Davutoğlu 2012, 7 ve 12).

Türk devletlerindeki şekil ve mânâ özelliklerine ve İslâm geleneklerine bağlı bulunan Osmanlı Devleti, müessese, teşkilât ve medeniyet konularında, kendi hayatını kurduğu XIV. yüzyıl başına kadarki Türk-İslâm devletlerinden her suretle etkilenmiş ve ilham almıştır (Gökbilgin 1977, 2-3). Nitekim Türkler, geniş bir coğrafya üzerinde sürekli hareket halinde oldukları için, birbirinden çok farklı, değişik toplum ve kültürlerle karşılaşmışlardır. Bu kültürlerden pek çok unsur aldıkları gibi o kültürlere de pek çok şey hediye etmişlerdir. Bu durum 
Türk kültürüne dinamik bir yapı kazandırmıştır (Ünal 2002, 54). Zamanla kendilerine ait devletleri, dinleri, töreleri, kültür, sanat ve edebiyatlarıyla belli bir medeniyet düzeyine ulaşmışlardır. Türk kültürü ve medeniyeti, Osmanlı toplum hayatı ve kültürüne, yaşayan bir gelenek olarak daha başlangıçtan itibaren bir şekilde damgasını vurmuştur (Lewis 2007, 8-9).

Klasik Dönem Osmanlı kültür ve medeniyeti özellikleri esas itibariyle üç temele dayandırılmaktadır. Bunlar; Türklerin Orta Asya'dan beri yaşattıkları örf, âdet ve gelenekler; İslamiyet'le birlikte kazanılan kültür değerleri ve Ön Asya, Anadolu ve Rumeli'de karşılaştıkları toplumlardan aldıkları kültür unsurlarıdır (Ünal 2010, 18). Bu unsurları kaynaştırıp yeni bir imtizacı gerçekleştiren ise, Türk'ün kendine has karakter ve vasıfları ile İslam'ın ona kazandırdığı tesamuh (hoşgörü), tevazu (ağırbaşlılık) ve vakâr (ağır başlılık) olmuştur (Ünal 2002, 54-59; 2010, 20). Nitekim Osmanlılar, fethettikleri yerlerdeki halkla kaynaşarak onların dini, örfi ve sosyal yapılarına karışmamışlardır. Onların vicdan hürriyetlerine saygı göstermişler, ağır vergiler altında ezilmiş olan yeni tebaasından belli bir vergi (Cizye) almakla yetinmişlerdir. Kanunlara aykırı olan keyfi hiçbir muameleye müsaade etmemişlerdir (Kazıcı 2016, 296-297). Dolayısıyla Osmanlılar, bir kavim olarak değil, bir hanedan, bir ordu, bir hâkim sınıf olarak ortaya çıkmış ve bu bütün içerisinde Bizans, Slav ve Osmanlı unsurları kaynaşmıştır (İnalcık 1996, 68). Osmanlı, uygulama alanına koyduğu İslami anlayış sayesinde cami, kilise ve havranın yan yana durduğu bir üst kültürü tesis etmiştir (Kazıcı 2016, 157. II. Mahmut'un 1826 'da ifade ettiği, "Ben tebaamın Müslüman'ını camide, Hristiyan'ını kilisede, Musevi’sini havrada fark ederim, aralarında başka bir fark yoktur" şeklindeki sözleri, Osmanlı'nın tebaaya yaklaşımını gösteren çok önemli bir örnektir. Bkz. Çilliler 2015, 53). Osmanlı, çeşitlilik ile bütünlüğü uzlaştırabilen büyük bir sentez kabiliyetiyle, bünyesindeki unsurları bir düzen içinde tutabilmiştir (Davutoğlu 2012, 13).

Osmanlı Devleti, dünya tarihini, bizatihi ekseninde yer almak suretiyle şekillendirmiş ve yönlendirmiştir. Yapısal olarak çok uluslu, çok dinli, çok dilli ve kurumsal olarak "uzun ömürlü" oluşu, ona tarihte ancak birkaç örneğiyle kıyaslanabilecek bir özgünlük ve özgüllük sağlamıştır. Osmanlı dönemi, Türk tarihinin kültür ve medeniyet açısından ulaştığı bir zirve olmuştur. 1400 yıllık İslam tarihinin hemen hemen yarısına tekabül etmektedir (Osmanlı Medeniyeti, Siyasetİktisat-Sanat, "Sunuş"dan, 2012).

Osmanlı medeniyetinin özelliği, sadece uzun bir dönemi kapsaması değildir. Hâkim olduğu coğrafya üzerindeki toplumlar üzerinde bıraktığı muazzam tesirlerdir. Bazıları Girit’teki Rum'un, Yemen'deki Arab'ın, Kuzey Afrika'daki Berberi'nin Osmanlı ile ne alakası var demektedir. Bu durum, bilgi eksikliğinden ve Osmanlı devri kültürünün özelliklerini kavrayamamaktan ileri gelmektedir. Orta Avrupa'dan Yemen'e, Afrika içlerinden Ukrayna bozkırlarına kadar olan geniş Osmanlı coğrafyası içerisinde hiçbir toplum yoktur ki Osmanlı kültürünün herhangi bir unsurundan etkilenmemiş olsun. Bu coğrafya içerisindeki toplumlar hiç Türkçe bilmese ve Müslüman olmasa bile, kimisi Osmanlı lisanından, kimisi Osmanlı nezaket ve zarafetinden, kimisi devlet idare etme kabiliyetinden, kimisi askerî disiplininden, kimisi yemek kültüründen, kimisi oturup kalkma adabından, kimisi Türk musikisinden, kimisi mimarisinden, kimisi giyim kuşamından, kimisi Osmanlı vakârından bir şekilde etkilenmiştir (Ünal 2002, 58).

\section{Göç ve Medeniyet İlişkisinin Osmanlı Anadolu'su ve Suriye'sinde Tezahürü: Göçmenlerin Sosyal, Kültürel ve Ekonomik Hayata Etkileri}

Kafesoğlu'nun belirttiği gibi milletlerarası ortak değerler bütünü olan medeniyetlerin (Kafesoğlu 1989, 15) ortaya çıkması ve birbirleriyle etkileşmesinde göçlerin önemli bir rol oynadığını söylemek mümkündür. Göç olgusunun yaşanmadığı ve tamamen durduğu yerde genellikle statik 
bir toplum yapısı ortaya çıkmış ve bu durum toplumun gelişmesine çoğu zaman engel teşkil etmiştir (Ortaylı 2006, 19). Dolayısıyla iç, dış, zorunlu, isteğe bağl1, tek tek ya da kitlesel olarak yapılan göçlerin sonucunda sosyal, kültürel, siyasi ve ekonomik anlamda toplumların yaşamlarında, uzun vadede önemli değişiklikler meydana gelmiştir. İnsanlar iskân edildikleri yerlerde yaşamak için evler inşa etmişler ve yan yana gelen evler, köylerin, kasabaların ve şehirlerin ortaya çıkmasında ana etkeni oluşturmuştur. Bu şekilde oluşan toplumlar devleti oluşturmuş, insanlığın maddi ve manevi varlığı böylece devam edegelmiştir (Çiçek \& Saydam 1998, 2).

Buradan hareketle söylenebilir ki göç, sadece bir coğrafi yer değiştirme hareketi değil, aynı zamanda dinamizm ve farklılıkların bir aradalı̆̆ıdır. Her ne kadar bir yanı ile çatışma, rekabet ve paylaşım alanları yaratsa da ortaya çıkan gerilim hallerinin çözümlerini mümkün kılacak enerjiyi ve sinerjiyi de oluşturmaktadır. Etno-kültürel ve dinsel farklılıkların birbirleriyle iletişim kurmasını ve böylelikle üçüncü alanların ortaya çıkmasını sağlamaktadır. Dolayısıyla bu yönleriyle göç, toplumsal ve siyasal barışın kurulmasında karar alıcılara olanaklar sağladığ 1 gibi ayrışmayı değil, birleşmeyi mümkün kılmaktadır (Kaya \& Erdoğan 2015, 5).

Meydana gelen göçlerle birlikte farklı fiziki yapılara, dillere, dinlere ve kültürlere sahip insanlar bir araya gelmişler ve etkileşim içinde olmuşlardır. Böylece yeni rrklar, kültürler, idare şekilleri ve yaşam biçimleri ortaya çıkmıştır. Bu yeni şartlar günümüz toplumlarının oluşmasına zemin hazırlamıştır (Karpat 2010b, 9).

Tarihsel süreçte göçlerden etkilenen en önemli yerler Avrupa ve Anadolu olmuştur (Bahadır 2008, 13). Nitekim 10.000 yıllık yerleşme tarihi olan Anadolu toprakları, farklı özelliklerde olan birçok göç deneyimini yaşamıştır. Bu deneyimler sonunda bugünkü kültürel çeşitlilik meydana gelmiştir (Tekeli 2013, 42). Bu çeşitlilikte, Osmanlı döneminde Balkanlar, Kafkasya ve Kırım'dan gerçekleşen göçlerin ayrı bir etkisi olmuştur.

Osmanlı döneminde Anadolu'ya gerçekleşen göçlerin, en başta nüfus oranında değişiklik meydana getirdiği görülmektedir. Zira salgın hastalık, kıtlık, savaş ve toprak kayıpları Osmanlı toplumunun nüfus artış hızını olumsuz yönde etkilemiştir. Özellikle 17. yüzyıldan sonra siyasi ve ekonomik nedenlerle Anadolu nüfusu azalmıştır. Köyler küçülmüş, "hâli ve harab" olanların sayısı artmıştır. XIX. yüzyılın ikinci yarısına gelindiğinde ise, uygulanan iskân politikası ve göçler sayesinde nüfusta azalma durmuş, artış başlamıştır (Güran 2014, 72). Bu dönemde Balkanlarda kurulan ulus devletlerde Müslüman-Türk nüfus oldukça azalırken, Anadolu'da önemli ölçüde artmıştır. Bununla ilgili olarak McCarty, 1878-1911 y1lları arasında Anadolu nüfusunun $\% 50$ düzeyinde arttı̆ğın hesaplamıştır. Bu da nüfusun y1lda yüzde 1.5 büyümesi demektir (McCharty 1998, 119; Tekeli 2013, 49).

Karpat, 1860-1900 yılları arasında Osmanlı nüfusunun \%80'ini aşan bir büyüme gösterdiğine işaret etmiştir. Osmanlı yönetiminin hesaplamalarına göre, nüfus 1874 ila 1884 y1lları arasında 4 milyon, 1884 ile 1894 yılları arasında 2,5 milyon ve bunu takip eden on yıl içinde 2,5 milyon artmıştır. Bunun büyük bir kısmı göçlerden kaynaklanmıştır. Yine, göçlerle birlikte Anadolu, Suriye ve Irak topraklarında yaşayan Müslümanların Hıristiyanlara oranı, Müslümanların lehinde değişmiştir. Osmanlı Devleti, ağırlıklı olarak Müslüman bir devlet haline gelmiştir. $\mathrm{Bu}$ dönüşüm, siyasi ve kültürel anlamda derin izler bırakmıştır. Zira devlet, Müslümanları gözeten bir politika gütmek zorunda kalmıştır (Karpat 2014, 132-134). Böylelikle MüslümanTürk unsurları gözeten, homojen nüfus politikasının izleneceği yeni bir döneme girilmiştir (Kocacık 1980, 180; İpek 2013, 155).

Göçmenlerin önemli bir kısmı, geldikleri ülkelerde yönetici sınıfa mensup kişiler olduklarından, beraberlerinde kendi sınıflarının yüksek kültürünü ve bilgi birikimini de getirmişlerdir. 
Bunun yanı sıra göçmenlerin içerisinde oldukça büyük sermayeye sahip insanlar da vardır. Şehirlerdeki ticari ve sınai faaliyetlere dâhil olmak için gayret sarf etmişlerdir. Yanlarında getirdikleri sermayeyle, toprak ve küçük çaplı ticaret alanında yatırımlar yapmışlardır. Düşük bir tahminle, göçmenlerin Osmanlı Devleti'ne getirdiği sermayenin 5 milyon lira civarında olduğu belirtilmektedir (Karpat 2014, 134).

Kitlesel göç akınlarının yoğunlaşmasıyla birlikte nüfus kaybının telafi edilmesinin yanı sıra üretim ve vergi gelirlerinin artırılmasının yolu da açılmıştır (İpek, 2013, 155; Kocacık, 1980, 180). Nitekim Babıâli, göçmenlerin ekonomik potansiyelini açığa çıkarmak ve bunu değerlendirmek arzusunda olmuştur. Özellikle II. Abdülhamit, bizzat bu konu üzerine eğilmiş ve göçmenleri, yetenekli oldukları alanlarda desteklemeye önem vermiştir. Örneğin, Bursa'ya gelen Bulgaristan göçmenlerinin gül sanayisi konusundaki deneyimlerinden istifade etmek için 70.000 gül fidanını Bursa'ya göndermiştir. Bu gül fidanları, Hazreti Emir civarındaki araziler ile "Dobruca, Panayır, Gülisan, Soğanlı" köylerine ait tarlalara ve Bursa'nın bostanlarına dikilmiştir. Neticede, bu fidanlardan 300 kıyye (400 kg.) gül üretimi gerçekleşmiştir. Bu güllerden Filibeli Hocazade Hafız Efendi, Balmumcu Hafız Galip Efeni ve Attar Hacı Ali Bey marifetiyle gül yă̆ı ve gül suyu üretilmiştir (Sarıbal 2018, 130).

Göçmenler, yeni ürünleri, tarımsal teknolojileri ve hayvanları beraberlerinde getirerek tarımsal üretim ve hayvancılığın gelişmesine katkı sağlamışlardır (Karpat 2010b, 187-188). Onların iskânı ile birlikte ilave insan gücünün devreye girmesiyle işlenmemiş ve bataklık olan araziler tarıma kazandırılmış ve zirai üretim artmıştır. Örneğin Çukurova bölgesinde farklı dönemlerde iskân edilen göçmenler, hem buradaki yerel bitkilerin hem de kendi yerleşim bölgelerinden getirdikleri kültür bitkilerinin üretimini yapmaya başlamışlardır (İpek 2006, 73). 1890 yılından itibaren Doğu Rumeli göçmenleri sayesinde Isparta'da gül yetiştiriciliği ortaya çıkmış ve kısa sürede gelişmiştir. Kiraz, tokaloğlu, kayısı, daldabir, kaba elma, bozdurgan, ferdinand armudu, şeker gibi ürünler de Kırım göçmenleri vasıtasıyla gelmiştir (Yılmaz 1999, 599).

Anadolu çiftçisi tarımda çoğunlukla kara saban, el orağı, tırpan, çapa gibi ilkel aletler kullanırken (Güran 2014, 75-77), göçlerin yoğunlaştığ 1 1890'dan sonra demir saban ve çeşitli tarım aletlerinin kullanımında büyük artış yaşanmıştır (Quataert 2000, 970-971). Bunun yanı sıra göçmenler, Anadolu tarımına pulluk ve yaylı araba gibi yeni teknolojileri de kazandırmışlardır (Tekeli 2013, 46). Rumeli göçmenlerinin kullandığg demir pulluk, eskiden beri kullanılagelen sabanın yerini almıştır (Karpat 2010b, 81). Yine, göçmenlerin demiryolu hatları boyuna iskân edilmeleri ve onların kullandığı dört tekerlekli arabaların, Anadolu'daki bir çift öküzün çektiği iki tekerlekli kağnılara nazaran daha fazla yükü, daha kolay taşıyabilmesiyle ulaşım şartları değişmiştir (Çelik 1996, 121-122; Ağanoğlu 2012, 117-118). Dört tekerlekli arabalar, daha etkin taşıma araçları olup örneğin bir atın taşıyacağı yükün beş katını taşıyabilmiştir. Yine, deve ve atla yapılan taşımacılığa nazaran daha az masraflı olmuştur. Dolayısıyla dört tekerlekli arabalar önemli bir avantaj sağlamıştır (Güran 2014, 79-80). Tarım ürünleri iç ve dış pazarlara daha rahat ulaşım imkânı bulmuş, ihracat imkânları artmıştır (Çelik 1996, 122; Ağanoğlu 2012, 118).

Tarımsal işletme sayısının artmasıyla birlikte 1873-1893 yılları arasında Osmanlı Devleti genelinde tarım yapılan arazilerde \%25 artış görülmüştür. Sanayide kullanılan tütün, pamuk ve gülyağı gibi ürünlerde önemli miktarlarda artışlar sağlanmıştır. 1890-1913 yılları arasında üretilen buğday miktarı \%17.2; 1885-1914 yılları arasında üretilen tütün miktarı \%100 artış göstermiştir (Çelik 1996, 121-122; Ağanoğlu 2012, 117-118). Eskişehir, Konya, Ankara üçgeninde buğday üretiminin gelişmesinde Kırım Tatarlarının payı yüksek olmuştur (Tekeli 
1998, 58). Balkan göçmenleri, Anadolu'da patates üretimine katkı yapmışlardır. Bilinmeyen bazı hayvan türlerini Anadolu'ya getirerek hayvancılı̆̆ın da gelişmesini sağlamışlardır (Çelik 1996, 122; Ağanoğlu 2012, 117-118). Çerkes göçmenler, yerleştikleri yerlerde et ve süt üretimi için hayvancılığın gelişmesine yardımcı olmuşlardır (Tekeli 2013, 153). At yetiştiriciliğinde de başarılı olan Çerkesler, getirdikleri Çerkes atları ile yerli atları melezleştirme yoluna da gitmişlerdir (Avagyan 2004, 75).

Dokuma sektöründe göçmenlerin tecrübelerinden yararlanıldığı görülmektedir. Nitekim Bursa'da yerleştirilen göçmenler, gerek kendi başlarına gerekse ortak olmak suretiyle dokuma tezgâhları alarak küçük çaplı fabrikalar kurmuşlardır. Böylece Müslüman girişimcilerin sayısının artmasında bir başlatıcı olmuşlardır. Bu yetenekleri, vilayet idaresinin de dikkatini çekmiş ve göçmenlerin, sslahhane bünyesinde bulunan çocuklara dokumacılık eğitimi vermeleri ve aynı zamanda para kazanmaları sağlanmıştır. Bu çerçevede Filibe ve Sofya göçmenleri 1slahhanede mevcut 26 tezgâh ile "şayak" adı verilen bir tür kaba kumaşın seri üretimini gerçekleştirmişlerdir (Sarıbal 2018, 130-131). Yine, Balkan Savaşları'ndan sonra Selanik’ten İstanbul'a göçenler İstanbul'da dokuma sanayisinin kurulmasında önemli rol oynamışlardır. Dolayısıyla bu göç hareketlerinin, ekonomik katkıları göz önüne alındığında, Osmanlı Devleti’nin küçülmesini bir ölçüde yavaşlattığı, özellikle XIX. yüzyılın ikinci yarısında Anadolu ekonomisinin canlanmasında önemli etkilerinin olduğu söylenebilir (Tekeli 1998, 58; Tekeli 2013, 46-47).

Göçlerin önemli bir etkisi de yerleşim organizasyonunda görülmektedir. Nitekim 93 Harbi ve sonrasında gelen göçmenler, köy-kent dağılımı üzerinde etkili olmuşlardır. Genellikle boş topraklar üzerine köyler kurulduğundan, nüfusun köy lehine artmasını sağlamışlar ve böylece yeni yerleşim tipleri ortaya çıkmıştır (Kocacık, 1980, 180; İpek, 2013, 155). Dama tahtası dizilişi biçimde görülen köy planlarıyla toplu köy tipi oluşturulmuştur. $\mathrm{Bu}$ tip yerleşimlerin, sosyal teması sağlamak, ulaşım ve taşımacılık maliyetlerini azaltmak, alt yapı kurma kolaylığı gibi yararları olmuştur. Göçmenler, bölgeye taş evler yapımını yeni bir teknik olarak getirmişler, evlerin oda, samanlık, avlu gibi düzenlemesinde yeni şekillerin yaygınlık kazanmasını sağlamışlardır (Çelik 1996, 127).

Göçmenlerin, yerleştikleri bölgedeki yerli ahalinin yaşam biçimlerine, mesleki örgütlenmelerine de etkileri olmuştur. Örneğin Bodrum'da yerleştirilen Giritli göçmenler, ev pansiyonculuğunun ilk müteşebbisleri olmuşlardır. Mübadele döneminde yerli halka nazaran daha modern bir yaşayışa sahip olan bu insanlar, gelenlere evlerini pansiyon olarak açan ve onları ilk kucaklayan kişiler olmuşlardır (Şakar 2019, 147). Bodrum'da yerleşen Giritlilerin, toplumsal hayata bakışta, kadınlara yaklaşımda da etkili oldukları görülmektedir. Nitekim 1950'lilerde ilçeler arası yapılan maçlarda, genç, yaşlı, çoluk çocuk, bilhassa siyah beyaz çizgili futalı (ipekli peştamal) futasız kadınlar birlikte sahanın etrafını doldurmuşlardır. O yıllarda, kadınlara gösterilen böyle bir müsamahanın, hiçbir çevre ilçede olmadığı, bu medeni tutumda mübadeleyle Bodrum'a gelen Girit kökenli halkın büyük rol oynadığ 1 belirtilmiştir. Giritlilerin, yerli halka oranla daha modern ve toleranslı oldukları ifade edilmiştir (Şakar 2019, 86).

Göçmenlerle birlikte Anadolu'daki gündelik hayatta da birtakım farklılıklar ortaya çıkmıştır. Örneğin "Muhacir arabası (üstü ve yanları örtülü, dört tekerlekli, yaysız araba)", göçmenlerle birlikte gündelik hayata dâhil olmuş ve yaygın bir şekilde kullanılan ulaşım aracı haline gelmiştir. Örneğin Mehmet Ziya Bey, XX. yüzyıl başlarında Bursa'dan Konya'ya yaptığı seyahatinde, göçmen arabalarına değinmiş ve Rumeli'den gelen göçmenlerin Anadolu'daki ulaşımı rahatlattığını belirtmiştir (Mehmet Ziya 2009, 28). Aynı şekilde Ömer Subhi Bey de 1890 yılında Bursa'ya yaptığı seyahatte, Rumeli göçmenlerinin arabacılık yaptığına dikkat 
çekmiştir (Ömer Subhi Bey 2007, 59).

Kısacası devlet, farklı özelliklere, deneyimlere sahip göçmenlerden yeni iskân sahalarında faydalanma yolunda önemli bir gayret sarf etmiştir. Bu yönde göçmenler de hem kendi imkânları hem de devletin desteğiyle farklı alanlarda önemli gelişmelere önayak olmuşlardır. Sosyal, kültürel, ekonomik alanlarda Anadolu'ya bir canlılık ve yenilik getirmişlerdir. Örneğin Bursa'da üzümleriyle meşhur Mora'dan göç eden bir göçmenin meyhanecilik, Rusçuk'tan göç eden bir göçmenin "muhacir arabasıyla" taşımacılık, Yanbolu'dan göç eden bir göçmenin "muhacir ayakkabısı" üreterek ayakkabıcılık yapması gibi bireysel girişimler şehirde önemli hareketliliğe vesile olmuştur (Sarıbal 2018, 132).

Anadolu'da iskâna elverişli araziler kalmadığı dönemde göçmenlerden bazıları, Suriye, Halep gibi vilayetlere de gönderilmiştir. Örneğin 1861'de, Şam'a otuz üç, Halep'e bin dört yüz doksan üç Kafkasya muhacirinin iskân edildiği görülmektedir (Saydam 2010, 131). Yine, 1878 yılının Şubat ve Eylül ayları arasında Bilad Eş-Şam'ın çeşitli limanlarına ulaşan Çerkes muhaciri sayısı 26.182 olarak verilmiştir (Berzeg 2006, 245-246). Dolayısıyla Suriye Vilayeti dahilinde çok sayıda Çerkes muhacirinin iskânına çalışılmıştır. Nitekim bir süre sonra iskân edilen Çerkes muhacirleri, ilk etapta yerli halk ile anlaşmazlık yaşamışlarsa da zamanla bölgeye uyum sağlamışlar ve Kasr gibi verimli arazileri işleyerek kendi ekonomik durumlarını iyileştirmeye başlamışlardır (Hülagü 2008, 152). Hatta belirli bölgelerde tarım kolonileri kurularak ekonomik olarak kalkınma yönünde önemli adımlar atılmıştır (Umar 2004, 161). Devlet, muhacirlerden demiryolu ve telgraf hatlarının korunması yönünde de faydalanmıștır (Umar 2004, 161). Zira Çerkesler, bazı bölgelerde, II. Abdülhamid döneminin büyük projesi olan Hicaz Demiryolu inşaatında, bedevi saldırılarına karşı kalkan görevi üstlenmişlerdir (Hülagü 2008, 123). Vladimir Hamed-Troyansky'nin tespitine göre de Çerkes göçmenleri, Osmanlı'nın son döneminde Amman'da ticari ve emlak faaliyetlerinin gelişiminde önemli rol oynamışlardır (Hamed-Troyansky 2017, 605-23).

Osmanlı yönetimi ve sonrasında Suriye'deki Çerkes nüfusun ana kitlesini askerler ve toprak sahipleri oluşturmuştur. Fransız Manda yönetiminde ise Çerkesler, iç güvenlik birimlerinde kolluk kuvveti olarak görev yapmışlardır. Bu dönemde Çerkes aydınları, Amin Samgugom liderliğinde Çerkes kültürünü muhafaza edecek adımlar atmışlardır. Kuneytra bölgesinde 40'a yakın okul açılmış ve 1928 'de Çerkesçe haftalık "Marc" gazetesi yayınlanmaya başlamıştır (Akbulat 2018, 7).

1990 sonlarında Suriye'deki Çerkeslerin sayısının yaklaşık 100 bin kişi olduğu tahmin edilmektedir. Bunların yarısından fazlası Şam ve banliyölerinde yaşamıştır. Halep, Minbedzh, Humus, Hama ve diğer şehirlerde yaşayan Çerkesler de vardır. 2011 yılına gelindiğinde Çerkesler, Suriye rejimimin üst düzey temsilciliklerinde yer alamamaya başlamışlardır. Suriye siyasal hayatından dışlanan Çerkeslerin bir kısmı askerlik ve bürokrasi dışındaki mesleklere yönelirken, büyük bir kısmı da ABD, Kanada, Batı Avrupa, Birleşik Arap Emirlikleri vd. ülkelere göç etmeyi tercih etmiştir (Akbulat 2018, 9). Son dönemde ortaya çıkan Arap Baharı süreci ve meydana gelen iç karışılıklar da ülkedeki geleceklerinden emin olamayan Kafkasyalıların bir kısmının Türkiye ve Rusya gibi ülkelere göç etmesine neden olmuştur (Kızılkaya \& Akay 2013, 150). Bu da başka bir göç hikayesini ortaya çıkarmaktadır.

\section{Göç ve Medeniyet İlişkisinin Osmanlı Afrika'sında Tezahürü: Göçmenlerin Bölgenin Kalkınmasına ve Yerli Halkın “Medenileştirilmesi”ne Etkileri}

Tolunoğulları ile başlayan Afrika'daki Türklerin hâkimiyeti, diğer Türk devletleriyle gelişmiş, 1517 yılında Mısır'ın Osmanlı idaresine girmesiyle başlayan yeni süreç ise 1918 yılında 
Osmanlı askerlerinin Trablusgarp'tan kesin olarak çekilişine kadar tam dört asır boyunca devam etmiş ve ardında köklü izler bırakarak sona ermiştir (Afrika'da Türkler'in hâkimiyeti ve kurdukları devletler ile ilgili detaylı bilgi için bkz. Kavas 2002, 575-588).

Afrika kıtasıyla Osmanlı Devleti'nin ilk münasebetleri ise XVI. yüzyılın ilk yarısında başlamıştır. Kuzey Afrika, Mısır ve Kızıldeniz liman şehirlerinde tesis edilen Osmanlı hâkimiyeti ilerleyen dönemlerde kıtanın yeni bölgelerine doğru genişlemiştir. Bir taraftan Kızıldeniz üzerinden Hint Okyanusu'na geçen denizciler Doğu Afrika sahillerini bilhassa Portekiz işgalinden korumaya çalışırken, diğer taraftan Büyük Sahra Çölü'nün güneyindeki Müslüman devletlerle karş1lıklı münasebetler kurulmuştur (Kavas 2003, 515).

Osmanlı Devleti'nin XVI. yüzyılın ilk yarısında Kuzey Afrika ülkelerinden Libya, Tunus ve Cezayir üzerinde kurduğu hâkimiyeti (Kuzey Afrika'daki Osmanlı hâkimiyetinin, XVI. yüzyılda Barbaros Hayrettin Paşa'nın Osmanlı Devleti'nin hizmetine girmesiyle başladığı söylenebilir. Pakalın 1971, 646), Akdeniz'in bir Türk gölü haline getirilmesine neden olmuştur. Afrika kıtasının kuzeyini kaplayan bu sahil şeridi, İslâm fethinin başladığı VII. yüzyılın ilk yarısından itibaren "Mağrib" olarak tarif edilmiştir. Osmanlılar ise Kuzey Afrika'daki eyaletlerine "Garp Ocakları" ismini vermişlerdir. Aslında bu isim de Mağrib kelimesiyle örtüşmekte ve "Batı Ocakları" manasina gelmektedir (Kavas 2003, 516-517).

Garp Ocakları'nda Osmanlı hâkimiyeti sağlandıktan sonra bir iskân siyaseti takip edilmiştir. Genelde Türk soylu yiğit gençler Anadolu'dan ve Akdeniz adalarından toplanarak yeniçeri yapılmak üzere bölgeye getirilmişlerdir $(\mathrm{Bu}$ dönemde örneğin Cezayir'e gönüllü olarak gideceklerin bütün masraflarının Hazine-i Hümayundan verileceği ilan edilmiş ve ilk Garp Ocakları Kuloğullarının geleneği açılmıştır. Böylece Cezayir'e ilk gönüllü dalgası olarak 4000 Anadolu yiğidi gitmiştir. Bkz. Karasapan 1960, 99). İstanbul, İzmir ve Antalya'da bulunan Cezayir, Tunus ve Trablusgarp eyaletlerinden görevli memurlar, ihtiyaca bağlı olarak topladıkları gençleri bu ocaklara taşımışlardır. Belli bir askeri disiplinden geçen bu cesur gençler, yeniçeri sınıfını meydana getirerek beylerbeyiler veya valiler zamanında hem onları korumak hem de şehirlerin güvenliğini sağlamakla vazifelendirilmişlerdir. Anadolu'da terk ettikleri yerlere dönmeyen bu insanlar kendilerine verilen görevleri bitirdiklerinde bu eyaletlerde kalmışlardır. Yerli ahalinin kızlarıyla veya ganimet olarak bu eyaletlere getirilen esir kadınlarla evlenerek kendi aile hayatlarını kurmuşlardır. Bunların evlatları zamanla her üç eyalette (Cezayir, Tunus, Trablusgarp) de yeni bir neslin doğmasına vesile olmuştur. Arap-Berberi ve İspanyol yerlilerin karışımından meydana gelen nesle "Mor" dendiği gibi Türklerin Kuzey Afrika yerlisi Müslüman kadınlarla ve diğer ülkelerden getirilen esir kadınlarla evliliklerinden doğan çocuklarına "Kuloğulları" denilmiştir (Kavas 2013, 114-115).

Dolayısıyla Osmanlı Devleti, klasik dönem iskân siyaseti gereği Türk-Müslüman nüfusu bölgeye nakletmiş ve "dışa dönük" bir iskân politikası takip etmiştir (Klasik dönem iskân sürecinde Kolonizatör Türk Dervişleri ve sürgünler önemli bir rol oynamıştır. Detaylı bilgi için bkz. Barkan 1942, 279-386; Barkan, 1949-1950, 56-78). Rumeli'de (Doğru 1999, 165-176) olduğu gibi ele geçirdiği Kuzey Afrika topraklarını da kendisi ve tebaası için kalıcı bir yurt yapmak istemiş ve bu yerlerin iskân, imar ve ihyasına büyük önem vermiştir. XVII. yüzyıla gelindiğinde ise, devletin uzun süren savaşlar yaşadığı ve memleket içinde asayişsizliğin, vergi adaletsizliğinin arttığı bir dönem söz konusu olmuştur. Bu dönemde, meskûn yerlerin boşaltılmas1 sonucunda, "harap ve sahipsiz yerlere aşiretlerin yerleştirilerek şen ve âbâdan (imar) edilmesi" gibi bir zihniyet oluşmuştur. Yani, bir "iç iskân meselesi”" ortaya çıkmıştır. XIX. yüzyılda ise iskân meselesi yeni bir boyut kazanmış ve kaybedilen topraklardan gelen göçmenlerin yerleştirilmesi meselesine ağırlık verilmiştir. Bu dönemde, siyasal coğrafyanın küçüldüğü 
ve dışarıdan içeriye dönük göçlerin yaşandığı görülmektedir (İpek 1996, 15-16; Halaçoğlu 1999, 581; Çelik, 1999/1, 71).

Kırım, Kafkasya ve Rumeli göçlerinin yaşandığı dönemde göçmenler için yeni iskân sahaları belirlenirken birtakım hususların esas alındığı görülmektedir. Nitekim II. Abdülhamit döneminde, Rusya hududundan Basra'ya kadar göçmen iskânında, "muhacirin iskânı nüfus-ı Islamiye'nin tezyidiyle (İslam nüfusunun artmasıyla) imar-ı memleket ve terakki-i varidat-ı devlete (devlet gelirlerinin artmasina) ve takviye-i sunuf-ı askeriyeye (askeri sinifa takviye yapılmasına) medar olacağına binaen nüfus-ı İslamiye'nin teksiri (artması) ve akvam-ı saireye rüçhanlarının (diğer milletlere üstünlüklerinin) muhafazası" ilkesi göz önüne alınmıştır. Dikkate alınan diğer bir husus ise, iskân için düşünülen arazilerin, "fenn-i harb nokta-i nazarından (savaş ilmi açısından)" hareketle belirlenmesi olmuştur. Dolayısıyla göçmenlere ilişkin meseleye, sanat ve ziraat erbabı insanların ithali olarak sadece iktisadi açıdan değil, "potansiyel asker tedariki" olarak da bakılmıştır (Deringil 1991, 436).

II. Abdülhamit dönemi iskân siyasetinde öne çıkan bu hususlar, Kuzey Afrika toprakları için de geçerli olmuştur. Nitekim bölgedeki son toprak parçaları olan Trablusgarp Vilayeti ve Bingazi Sancağında Müslüman nüfusu artırmak ve nüfuzu sağlamlaştırmak öncelikli hedeflerden biridir. İkincisi, güvenliği tehdit edebilecek herhangi durumunda burada hazır bir askeri gücü bulundurmak olmuştur. Bu konuya, Bingazi ileri gelenlerinden Salim Efendi'nin 1891 yılında kaleme aldığı layihada da temas edilmiştir. Salim Efendi, 1.000 hane kadar Çerkez göçmeninin Bingazi'de iskân edilmesiyle onlardan asker temin edilmesi gibi faydalar sağlanabileceğine (BOA, Y. MTV., Dosya No: 53, Gömlek No: 71, 12 Ağustos 1307/24 Ağustos 1891) dikkat çekmiştir. Yine Girit göçmenlerinin bölgede iskân edilmesiyle, "muhtemel bir sefer esnasında devletin her istediği noktaya sevk edebileceği askeri bir kuvvetin hazır bulunmasına" (BOA, DH. MHC., Dosya No: 48, Gömlek No: 71, Lef: 8-2, 2 Nisan 1318/15 Nisan 1902) hizmet edileceği belirtilmiştir. Üçüncü olarak da, yukarıda da belirtildiği üzere, bölgenin şenlendirilmesiyle imar-ı memleket ve terakki-i varidat-ı devlete hizmet etmek yani üretimi ve gelirleri artırarak hem bölge hem de ülke ekonomisine katkı sağlamak amaçlanmıştır. Nitekim boş ve harap yerlerin şenlendirilmesi ve ziraata açılabilmesi için konar-göçerlerin yerleşik hayata geçirilmeleri gerekli görüldüğünden (Tekeli 1998, 53), Babıâli, bu anlamda Trablusgarp'taki urban (göçebe Arap aşiretleri) kabilelerini de yerleşik hayata geçirmek istemiş ve bunlara örnek teşkil etmesi ve kabilelerin iskân edilmesini kolaylaştırmak amacıyla Trablusgarp'a göçmen göndermeye çalışmıştır (İpek 1999, 159).

XIX. yüzy1lda Osmanlı Devleti'nde var olan ziraî ekonomik kaynak dengesinde emek kıt, toprak ise bol faktördür. 1831 y1lı için Osmanlı Avrupa'sında kilometre kareye isabet eden kişi sayısı 15,5, Anadolu'da ise 6,1'dir. Nitelik ve nicelik açısından emeğin kıtlığı, daha fazla toprak işlenmesine engel olmuştur (Çelik 1996, 121). Nitekim Trablusgarp Vilayeti ve Bingazi Sancağı'nın yüzölçümü de bir milyon kilometre kareden fazla olmasına rağmen ahalisi 1,5 milyon kadar yoktur. 1910 yılı Meclis-i Mebusan görüşmelerinde, Osmanlı topraklarının neredeyse yedide birini teşkil eden böyle büyük bir bölgede, gayet az ahali ile elde edilebilecek mali gücün çok sınırlı olduğu belirtilmiştir. Hâlbuki Bingazi mebusu Ömer Mansur, Cebel-i Ahdar'ın zirai zenginliğinden övgüyle bahsetmiş (Meclis-i Mebusan Zabıt Ceridesi, 24 Mayıs 1326 (6 Haziran 1910, Pazartesi) Oturumu, 30), diğer bir Bingazi mebusu Yusuf Şetvan Bey ise, arazinin bire yüz ve yüz elli verdiğine (Meclis-i Mebusan Zabıt Ceridesi, 24 Mayıs 1326 (6 Haziran 1910, Pazartesi) Oturumu, 46) işaret etmiştir. Dolayısıyla araziyi işleyecek insan gücüne ihtiyaç vardır. Bu anlamda muhaceretin ortaya çıkardığı ilave kalifiye emek gücü önemli bir gelişme olmuştur. 
Osmanlı'da kırsal kesimdeki kitlelerin düşük eğitim düzeyi nedeniyle çiftçilik işlerinde özellikle sorun çözebilecek "bilgili ve yetenekli kimseler bulunamaması" tarımın en temel problemlerinden birini oluşturmuştur (Güran 2014, 61). Osmanlı'nın son döneminde yaşamış olan Parvus Efendi de arazinin fazlalığına rağmen işleyecek insan gücünün eksikliğine dikkat çekmiş ve buna çözüm olarak göçmenlerin tarım alanlarında kullanılmasının önemine vurgu yapmıştır. Bu konudaki düşüncelerini şu şekilde ifade etmiştir:

“...Türkiye'de çok toprak bulunmaktadır. Almanya ve Ingiltere gibi toprakların dörtte birinde tarım yapılan sanayi ülkeleri bir yana, Rusya'nin Avrupa kitasindaki topraklarinin \%40'l, Batı Hindistan topraklarının \%35'i tarıma açıtır. Asya'daki Osmanl topraklarında ise bu oran \%2.8'dir. Işste tüm sorun toprağı işleyecek yeterli ve yetenekli işçinin nereden ve nasıl bulunacağıdır. Osmanlı nüfusu, Avrupa'da geliştirilen teknikleri uygulamak koşulu ile tarımı gelişstirmeye yeteneklidir. Türkiye'ye gelecek göçmenler örnek bir tarım yöntemi uygularlarsa çok önemli bir rol oynayabileceklerdir..." (Parvus Efendi 1977'den aktaran Gökbunar 2004, 238).

Osmanlı Hükümeti, Trablusgarp ve Bingazi toprakları hakkında bölgedeki görevliler vasıtasıyla bilgi toplamış ve buradan gelen raporlar doğrultusunda hareket ederek merkezden uzak bu topraklardaki varlığını korumaya çalışmıştır. Nitekim bölgeden gönderilen raporlarda, arazinin iskân için uygunluğuna dikkat çekilirken bu anlamda bölgeye göçmenlerin sevk edilmesi fikri ortaya çıkmıştır. İskân mahalli olarak özellikle Bingazi'den Derne'ye kadar uzanan Cebel-i Ahdar bölgesine vurgu yapılmıştır. Nitekim Cebel-i Ahdar'ın kuzeyinde denize giden derelerin bulunduğu bir plato, nehir yatakları, boğazlar yer alırken güneyinde çöle uzanan yarı bozkır bölgesi vardır. Kuzeyinde yıllık yağış miktarı 450 ila $500 \mathrm{~mm}$ arasında değişmektedir. Yeşil platonun mevsimsel yağmuru yıl boyunca yer altı sarnıçlarını ve kuyuları doldurmaktadır. Burada Mayıs'tan Eylül'e kadar yağış etkili olmakta ve sonbahar mevsiminde bedeviler arpa, buğday ve diğer mahsulleri ekmektedirler (Benzabih 1982, 196-97; Gall 1986, 184-85).

1870-1881 yılları arasında Trablusgarp ve Bingazi'de görev yapan Binbaşı Abdülvahid, Bingazi coğrafyası hakkında bilgi verirken, arazinin durumuna göre her çeşit mahsulatın, meyvesi bol her cins ağacın yetiştiğini, çok faydalı bitkiler ve madenlerin bulunduğunu belirtmiştir (Binbaşı Abdülvahid 2020, 53). Ali ve Ahmed Nuri Efendiler tarafından kaleme alınan H. 1301/M. 1883-1884 tarihli risalede de, özellikle Bingazi ile Derne arasındaki sahil bölgesine dikkat çekilerek, bu mevkiinin son derece mamur ve abadan olduğu belirtilmiştir. Yapılan tespite göre Bingazi ile Derne arasında çok sayıda zeytin ağacı ve geniş bir ormanlık arazi bulunmaktadır. Zeytinin en fazla olduğu yerler; Ayn-ı Şehhat, Vadi-i Nasrib, Vadi-i Cerib ve Klkreb'dir. Buralarda ziraata elverişli geniş araziler mevcut olup, eğer önem verilirse kısa bir süre içinde memleketin en mamur yeri haline gelebileceği ifade edilmiştir (Ali ve Ahmed Nuri 1301, 112-113). Binbaşı Ömer Subhi tarafından hazırlanan H.1307/M.1889-1890 tarihli eserde ise Cebel-i Ahdar'a işaret edilerek; "birçok meralara ve ufak tefek çağlayanlara mâlik olduğu cihetle vilayetin en ziyâde iskâna kabiliyetli bir kısmı add olunabiliyor." (Ömer Subhi Bey 1307, 57) denilmiş ve bölgenin önemine dikkat çekilmiştir. II. Abdülhamid tarafindan Senûsî şeyhi Mehdî es-Senûsî ile görüşmek üzere görevlendirilen ve 7 Ekim 1895'te Bingazi'ye ulaşan Sâdık el-Müeyyed (detaylı bilgi için bkz. Bostan 2008, 399-400) de bölgeyle ilgili hazırladığ raporunda, göçebe Arapların çalışmadığına değinerek, "göçmenler bu topraklara yerleştirilirse arpa ve buğdaydan önemli miktarda verim alınabileceğini”" (Sâdık el-Müeyyed 2018, 26-27) belirtmiştir. 
Derne ile Bingazi arasındaki sahilde ve dağlarda tatlı su kuyuları, sarnıçları, ihmal edilmiş zeytinlikler ve ormanlar olduğu (BOA, ŞD. DH., Dosya No: 2325, Gömlek No: 32, 17 Cemaziyülevvel 1297/27 Nisan 1880) halde bölgenin yerli ahalisi olan urban (göçebe Arap aşiretleri) tarafından bunlardan istifade edilememiştir (1662' de hac maksadıyla bölgeden geçen Ayaşi, burayı antik harabeler/harabe şehirler sergisi olarak tabir ettikten sonra Cebel-i Ahdar'a da "yol kesici bedevilerin yurdu" demiştir. Ayrıca bu bölgede herhangi bir hükümetin bulunmadığını; bölge ahalisinin, bedevi kabile reislerinin azgınlıklarına tahammül etmek zorunda olduğunu belirtmiştir. Bkz. Taş 2016, 159) Nitekim bu konuya temas eden Ali Kemali Paşa, “(...)bă̆ ve bahçeler işlenmemekte, su kuyuları dahi hakklyla değerlendirilmemektedir. Zeytinlik ve ormanlardan bilinçsizce faydalanılmaktadır. Ağaçların ince dalları ve yaprakları kesilip keçi ve deve gibi hayvanlara yedirilmekte, hatta ağaçlar kirtlip veya kökünden kesilip yakılmaktadır. Bazen de kabuklart soyulup beyhude telef edilmektedir." (BOA., ŞD. DH., Dosya No: 2325, Gömlek No: 32, 17 Cemaziyülevvel 1297/27 Nisan 1880) demiştir. Yine, bölgede 1870-1881 yılları arasında görev yapan Binbaşı Abdülvahid, Derne yakınlarında milyonlarca zeytin ve ardıç ă̆acının olduğunu fakat Araplar arasında bir kıymet ifade etmediğini (Binbaşı Abdülvahid 2020, 57); ayrıca çok miktarda tuzun bulunduğunu, fakat yakınında yerleşme olmadığından muhafaza edilemediğini ve urban tarafindan zayi edilmekte olduğunu belirtmiştir (Binbaşı Abdülvahid 2020, 54). 1891 yılında bölgeden gönderilen resmi bir evrakta da çadırlarda ikamet eden ve göçebe olarak hayatlarını devam ettiren halk nedeniyle tarım alanında rahat ve güvenli bir şekilde faaliyet yürütülemediği belirtilmiştir. Ayrıca, Bingazi ve Derne'de yaşayan göçebelere vatan sevgisini ( $h u b b$-l vatan) öğretmek için onların da askere alınmaları gerektiği öne sürülmüştür. (BOA., Y. PRK. AZJ., Dosya No: 19, Gömlek No: 22, 16 Şevval 1308/25 Mayıs 1891).

Bölgedeki yerli halkın büyük bir bölümünün göçebe Arap aşiretlerinden oluşması ve onların toprağa yerleşmeyi kabul etmemekte gösterdikleri direnç (Çınar 2012, 20), hem yerel idareyi hem de hükümeti bir çözüm arayışına yöneltmiştir. Bu çalışmalar esnasında bölgedeki arazilerin nitelikli insan gücü ile işlenmesi sonucunda tarımsal kalkınmanın sağlanabileceği düşünülmüştür. En nihayetinde bu insan gücünün göçmenlerden karş1lanabileceği üzerinde durulmuş ve bölgede, istenilen menfaatleri elde etmek için "gayretsiz ve vahşi âdemler" olarak görülen göçebe Araplar yerine masrafsız ve külfetsiz bir yol olarak görülen göçmenlerden yararlanma yoluna gidilmiştir (BOA., MVL., Dosya No: 762, Gömlek No: 37, Gurre-i Zilkade 1278/May1s 1862).

Bölgedeki ahalinin durumundan hareketle, göçmenlerin iskân edilmesiyle birlikte ulaşılmak istenen önemli hedeflerden birisi de yerli ahalinin, arşiv belgesinde belirtildiği gibi, "daire-i medeniyete ithali”, yani "medenileştirilmesi/uygarlaştırllması" hususu olmuştur. Rumeli veya Kafkasya'dan gelen göçmenlerin burada iskân edilmeleriyle hem göçebe Araplara örnek olacakları hem onları yerleşik hayata teşvik edecekleri, hem de onların medeniyet dairesine alınmalarına, yani yerleşik ve üretici hale gelmelerine hizmet edecekleri düşünülmüş ve bunun devlet menfaatine büyük katkı sağlayacağı belirtilmiştir. Nitekim 1891 yılı Ağustos ayında yerel idareden, Göçmen Komisyonu Genel Müdürlüğü'ne gönderilen bir resmi evrakta, özetle, "Bingazi civarında muhacirin iskân edildiği takdirde göçebe olan Arapların dahi yerleşik hayata rağbet edecekleri ve bu durumun ise onların "daire-i medeniyete ithalini (medenileştirilmesini)" kolaylaştıracă̆ ve bu yüzden mülken ve siyaseten faydalar sağlanacağl'”' (BOA, Y. PRK. KOM., Dosya No: 8, Gömlek No: 4, 3 Ağustos 1307/ 16 Ağustos 1891) ifade edilmiştir. Yine 1891 yılı Eylül ayına ait resmi bir evrakta; "Bingazi sancă̆ı dâhilindeki mahallere muhacirin iskân edildiği takdirde oraların iki üç sene zarfinda şen ve imar olacă̆ı gibi göçebe Arap aşiretlere dahi yerleşme hevesi, isteği gelerek onların da 
“daire-i medeniyete ithalinin (medenileştirilmesinin)" kolaylaşacağı...” (BOA, İ. DH., Dosya No: 1244, Gömlek No: 97479, 10 safer 1309/15 Eylül 1891; Osmanlı Belgelerinde Kafkas Göçleri 2012, 461-462) belirtilmiş ve bu konunun önemine bir kez daha işaret edilmiştir.

Bölgede eksik olan insan gücünün sağlanması ve göçebe Araplara örnek olmaları için başlangıçta Kafkasya ve Rumeli göçmenlerinin bölgeye iskân edilmesi hedeflenmiştir. Bunun da ilk adımı 1862 yılında atılmış ve Çerkez ve Nogay göçmenlerinin bölgeye yerleştirilmesi amaçlanmıştır. Göçmenlerden 1.000-1.500 ailenin Bingazi'ye getirilerek eski bir yerleşim yeri olan ve zeytinliğin tam merkezinde bulunan Ayn-ı Şehhat'a yerleştirilmesi düşünülmüştür (Şehhat: Derne ile Tobruk arasında ve Derne'nin 5-6 mil açığında Şehhat Deresi'nin kenarında yer alan bir beldedir. Belde eski Sirenayka Hükümdarlığı'nın başkenti olup, içerisinde birçok tarihi yapıyı barındırmaktadır. Bkz. Özata 2015, 78). Böylece hem göçmenler, havası ve suları güzel olan bir yerde zeytinliklerden ve gayet mahsuldar araziden istifade edebilecek, hem de devlet, eski bir yerleşim yerinin işlenmesi ve imar edilmesiyle kazanç sağlayacaktır (BOA., MVL., Dosya No: 762, Gömlek No: 37, Gurre-i Zilkade 1278/Mayıs 1862). Fakat bir süre sonra göçmenlerden büyük bir bölümünün Anadolu'ya yerleştirildiği ve gönderilecek göçmen kalmadığı; aynı zamanda soğuk iklime alışık olan göçmenlerin, bölgenin çok sıcak olmasından dolayı gitmekten kaçındıkları merkezden bildirilmiştir (BOA., MVL., Dosya No: 762, Gömlek No: 37, 27 Zilkade 1278/26 Mayıs 1862; Çınar 2012, 20-24).

$\mathrm{Bu}$ ilk girişimden sonra birkaç defa daha Kafkas ve Rumeli göçmenlerinin bölgeye iskân edilmesine çalışılmıştır. Bu girişimler XIX. yüzyılın sonuna kadar da devam etmiştir. Fakat Kafkas ve Rumeli göçmenlerinin bölgede iskânı bir türlü gerçekleştirilememiştir. Bunda bölgenin uzaklı̆̆l, ekonomik sıkıntılar ve coğrafi şartların farklılı̆̆ nedeniyle göçmenlerin gitmek istememesi rol oynamıştır (İskân girişimleri ve karşılaş1lan zorluklara dair bkz. Osmanlı Belgelerinde Kafkas Göçleri 2012, 382, 388-389, 448, 461-462). Neticede, Rumeli ve Kafkas göçmenlerinin Bingazi'nin iklimine dayanamayacakları anlaşılmış ve bu çözüm önerisinden vazgeçilmiştir. Göçmenlerin, Samsun, Sinop ve Sivas taraflarında iskanlarının daha uygun olacağı kararlaştırılmıştır (BOA., HR. İD., Dosya No: 16, Gömlek No: 12, 9 Teşrinisani 1307/21 Kasim 1891).

XIX. yüzyılın sonunda ortaya çıkan Girit göçleri ile birlikte Bingazi tekrar gündeme gelmiştir. Nitekim yüzyılın sonunda Girit’te meydana gelen isyanlar sırasında Müslümanlar zor günler geçirmişlerdir. Adada yaşananlara dair Girit Vali Vekili İsmail Hakkı Paşa tarafından 8 Eylül 1898 tarihinde gönderilen bir evrakta şunlar belirtilmiştir:

"Girit'te Hıristiyanlar tarafindan kendilerine yapılan baskı ve zulümden dolay ev, eşya ve arazilerini terk ederek Kandiye'ye iltica eden 40 bini aşkın Müslüman, iki seneden beri çok zor durumda kalmuştır. Terk ettikleri evleri taş üstünde taş kalmayacak bir şekilde Hıristiyanlar tarafindan tahrip edilmiştir. Sahip oldukları zeytin ağaçlarının büyük bir kısmı kesilerek yakılmıs ve kalanlarının da kesilmesine devam edilmiştir. Bütün bunların yanında Kandiye'ye göç esnasında binden fazla Müslüman, Hiristiyanlar tarafindan katledilmiştir. Müslümanların içinde bulunduklarl bu durum ahali tarafindan defalarca büyük devletlerin hariciye nazırlarına ve konsoloslarına bildirildiğ halde Müslümanların yararına olacak hiçbir teşebbüste bulunulmamıştır" (Arşiv Belgelerine Göre Balkanlar'da ve Anadolu'da Yunan Mezâlimi-I: Balkanlar'da Yunan Mezalimi 1995, 231-232). 
Yaşanan bu olaylar karşısında başlangıçta, Giritli Müslüman ahalinin Osmanlı'nın başka bölgelerine göç ettirilmesi teklif olunmuş, fakat Babıâli bunu reddetmiştir. Çünkü Müslüman halk giderse, ada da kesin olarak elden çıkmış olacaktır. Devletlerin ısrarı, hatta halkın arzusu bu kararı değiştirememiştir. Osmanlı Devleti askerlerini çekmeyi de kabul etmemiştir. Amiraller bir çare olarak Müslüman halkı, Osmanlı ve Avrupalı askerlerden kurulu bir hattın gerisine çekmişlerdir. Fakat bir süre sonra Osmanlı Devleti, Müslüman halkı koruyamayacağı gerçeğiyle karşı karşıya kalacak ve göçü kabullenecektir (Kürşat 1999, 69).

Adadan ayrılmak zorunda kalan Müslüman ahalinin bir kısmı hem doğruca Girit’ten hem de Aydın Vilayeti üzerinden Bingazi’ye geleceklerdir. Bu süreçte Osmanlı Hükümeti tarafından planlı bir sevkiyatın ve iskânın gerçekleştirilmesi söz konusu olacaktır (Girit Müslümanlarının zorunlu göçü ve Bingazi mutasarrıflığı dâhilinde yürütülen iskân çalışmaları ile ilgili detaylı bilgi için bkz. Menekşe 2018).

Girit göçmenlerinin bölgede iskânları gündeme geldiğinde, daha önce olduğu gibi benzer hususlara dikkat çekilmiş ve nüfusu artırma, askeri gücü teşkil etme ve ekonomik kalkınmayı sağlama üzerinde durulmuştur. Nitekim yerel idareden gönderilen raporlarda, arazinin işlenmeye elverişli olduğu ve uzun y1llar gelir sağlanabileceği üzerinde sıkça durulmuştur. Dolayısıyla Osmanlı Hükümeti de Girit göçmenlerini bölgeye sevk ederek boş bırakılmış toprakların işlenmesini sağlamayı ve bunları verimli ve kârlı tarım arazilerine dönüştürmeyi amaçlamıştır.

1900 y1lı Mart ayında toplanan Bingazi İdare Meclisi’nde bölgenin coğrafi durumuna dair önemli hususlara değinilmiştir. Özellikle Cebel-i Ahdar bölgesine ve burayı ihya eden eski kavmin merkezi Ayn-ı Şehhat'a dikkat çekilmiştir. Burada, taş kemerleriyle vücuda getirilen kapalı ve açık büyük su sarnıcı ve kuyuları ile zeytinyağını sıkmak için de 1,5 metre uzunluğunda yuvarlak değirmen taşlarının bulunduğu, kısacası verimli ve işlenmeye hazır bir arazisinin olduğu belirtilmiştir (BOA, DH. MHC., Dosya No: 42, Gömlek No: 6, Lef: 11-2, 4 Mart 1316/17 Mart 1900). Nitekim bölgeyle ilgili fikir sahibi olan göçmenler de arzuhallerinde, vaktiyle birkaç milyon ahaliyi beslemiş, refah ve saadetlerini temin etmiş olan Cebel-i Ahdar bölgesinin, toprağının verimliliğine ve kabiliyetine değinmişler, burada iskân edilmeleri durumunda, Girit'te kaybettikleri refah ve saadetlerini kazanabileceklerini belirtmişlerdir (BOA, DH. MHC., Dosya No: 48, Gömlek No: 71, Lef: 4-1, 11 Temmuz 1317/24 Temmuz 1901). Nitekim vatanları Girit, zeytin ve zeytinyağı üretimi konusunda köklü bir tarihe sahiptir. Girit’te yapılan kazı çalışmaları esnasında zeytinyağı üretimine dair elde edilen buluntular, buradaki üretim teknolojinin (zeytinyağı presi) M.Ö. 2000-1500 y1llarında uygulandığını göstermiştir (İplikçi ve Bakır 2018, 16). Girit’te zeytinyağının modern tarihi ise, XVII. yüzyılın ikinci yarısında adanın Osmanlılarca fethedilmesiyle başlatılmaktadır. Zeytincilik, Venedik egemenliğinin son döneminde yaygınlaşmış olmakla birlikte, Osmanlılar zamanında sektör hem nicel hem de nitel bir sıçrama yapmıştır. Eldeki tüm göstergeler, zeytinyağının hem üretiminde hem de ihracatında XVII. yüzyıldan XVIII. yüzyıla geçilirken önemli bir artış yaşandığına işaret etmektedir (Hadzııssıf 2018, 96-105). Dolayısıyla ada halkının büyük bir kısmı geçimini zeytin üretiminden ve zeytin yan ürünlerinin oluşturduğu sanayi faaliyetlerinden sağlamıştır. Giritli Müslümanların göçünden kısa bir süre önce, 1890'lıların başında gerçekleştirilen sayımda 6 milyona yakın zeytin ağacı tespit edilmiştir. Adanın Osmanlı hâkimiyetine alınmasından bu yıllara kadar geçen zaman diliminde ağaç sayısında on kat bir artış meydana gelmiştir (Adıyeke \& Adıyeke 2006, 157). Dolayısıyla Giritliler, çok eski tarihlerden itibaren Girit’tin ekonomisinde önemli bir yer tutan zeytin ve zeytinyağı üretimi ile meşgul olmuşlar ve bu konuda her geçen gün kendilerini geliştirmişlerdir. Nitekim devletin, 1891 y1lında, Cebel-i 
Ahdar'da bulunan zeytin ağaçlarının aşılanması ve bakımı için yetenekli Giritli Müslümanlardan istifade ettiği görülmektedir (BOA, Y. PRK. A., Dosya No: 6, Gömlek No: 78, 2 Safer 1309/7 Eylül 1891).

1884 yılı Derne doğumlu ve aslen Karaman kökenli olan Sadullah Koloğlu (ayrıntılı yaşam öyküsü için bkz. Koloğlu 2001), anılarında, devletin göçmenleri bölgeye iskân ederek burayı uygarlaştırmayı planladığını belirtmiş ve şu ifadelere yer vermiştir:

"Girit'ten kaçanlar genellikle İzmir'e sığınmayı yeğlerlerdi. İklimi ve toprak yapisı onlara daha uygun düşüyordu. Daha az oranda Bingazi ve Derne'ye gelenler de olmuştu. Hatta Osmanl Hükümeti, ziraat tekniğinde çok ileri olan Giritlileri toplu halde bizim bölgeye yerleştirip buraları kalkındırmayı, daha açı bir şekilde uygarlaştırmayı bile planlamıştı" (Koloğlu 2001, 11).

Koloğlu'nun da belirttiği gibi bölgede, ekonomik kalkınmanın sağlanması amacının yanı sıra bir başka önemli nokta da buradaki göçebe aşiretlerin "medeniyet dairesine" alınmaları veya bölgenin uygarlaştırılması hususu olmuştur. Göçebe aşiretlerin yerleşik ve üretici hale getirilmelerinde göçmenlerin örnek teşkil etmeleri hedeflenmiştir.

Bu konuda araştırma yapan Lorenz, on binlerce Giritli Müslümanın adadan zorla sürgün edilmesi, Osmanlı Devleti'nin Girit'teki egemenliğine ağır bir darbe vurmuş olmasına rağmen Osmanl yetkililerinin, bu zorunlu göçü, Bingazi ve Derne arasındaki geniş, verimli alanda ikinci Mısır'l yaratma planlarını gerçekleştirmek için hayırlı bir firsat olarak değerlendirdiklerini ileri sürmüştür. Yine, Osmanlı yetkililerinin, Giritli göçmenleri, tarımsal kalkınma yoluyla çok ihtiyaç duyulan gelirleri elde etmek ve daha da önemlisi Kuzey Afrika'da sağlam bir imparatorluk dayanağ 1 oluşturmak için emeğe, beceriye ve arzu edilen varlıklara sahip tarımsal yerleşimciler olarak gördüklerini belirtmiştir (Lorenz 2021, 92).

Başlangıçta 1.000 hanede 5.000 kişilik bir göçmen grubunun Bingazi ve Derne arasındaki bölgeye yerleştirilmesi amaçlanmıştır (BOA, İ.MTZ.GR., Dosya No: 33, Gömlek No: 1363, 30 Mayıs 1315/2 Haziran 1899). Bu amaç doğrultusunda 1899 yılı içerisinde Bingazi'ye sevkiyatın yapıldığı görülmektedir. Örneğin 5 Ağustos 1899 tarihinde, Girit’ten ayrılan 181 kişi doğrudan Bingazi'ye ulaşmıştır (BOA, DH. MKT. PRK., Dosya No: 2197, Gömlek No: 137, 24 Temmuz 1315/5 Ağustos 1899). Yine, 20 Ağustos 1899 tarihinde, 800 Girit göçmeni, İzmir'den hareket eden Nimet-i Hüdâ vapuru ile Bingazi'ye sevk edilmiştir (BOA, DH. MHC., Dosya No: 19, Gömlek No: 23, Lef: 1-1, 8 Ağustos 1315/20 Ağustos 1899). Neticede gerek İzmir'den gerekse Girit'ten yaklaşı 800 hanede 4 bin nüfusun Bingazi'ye geldiği (BOA, DH. MHC., Dosya No: 42, Gömlek No: 6, Lef: 13-1, 4 Mart 1316/17 Mart 1900; BOA., A. MKT. MHM., Dosya No: 506, Gömlek No: 11, 5 Şubat 1315/17 Şubat 1900) tespit edilmiştir. Göçmenlerin bölgeye ulaşmasıyla birlikte de ihtiyaçlarının karşılanması ve yerleştirilmeleri için çalışmalara başlanmıştır. Fakat merkezi hükümetten talep edilen parasal kaynağın zamanında temin edilememesi, yerel yönetimden kaynaklanan aksaklıklar, iskân coğrafyasının zorlu şartları gibi sebeplerden dolayı bu çalışmalar istenilen düzeyde olmamıştır. Hatta iaşe ve barınma gibi temel ihtiyaçlar konusunda üç sene süren sıkıntılar nedeniyle göçmenler iskândan ümitlerini kesmişler ve bölgeyi terk etmeye başlamışlardır (BOA, A. MKT. MHM., Dosya No: 506, Gömlek No: 11, 14 Eylül 1315/26 Eylül 1899). Örneğin Susa (Sussa) ve Tulmayta mevkilerine sevk edilen Girit göçmenleri, meskenlerinin inşa edilememesi ve Susa'da ihtiyaç duyulan suyun zamanında temin edilememesinden dolayı zor günler geçirmişlerdir (Su sorunuyla ilgili olarak, 11 Kasım 1804 tarihinde Trablus şehrine seyahat eden Ali Bey, Trablus'ta memba suyu ya da nehrin bulun- 
madığını, halkın sularını yağmur sularından tedarik ettiğini ve bu suları her evde bulunan su sarnıçlarında muhafaza ettiklerini, ayrıca banyo, abdest ve diğer ihtiyaçlar için de kuyulardan çektikleri tuzlu suları kullandıklarını belirtmiştir. Domingo Badia y Leblich (Ali Bey) 1816, 228-233). Durum böyle olunca da bir süre sonra bölgeden ayrılmaya başlamışlardır (BOA., DH. MHC., Dosya No: 27, Gömlek No: 59, Lef: 3-1, 27 Mayıs 1316/10 Haziran 1900). Nitekim 1902 y1lına gelindiğinde bölgede 1.315 nüfus göçmen kalmıştır (BOA., DH. MHC., Dosya No: 48, Gömlek No: 71, Lef: 9-1, 30 Mart 1318/12 Nisan 1902; BOA., A. MKT. MHM., Dosya No: 506, Gömlek No: 11, 30 Mart 1318/12 Nisan 1902).

Zorlu şartlar nedeniyle çok sayıda göçmen, yiyecek getiren veya Bingazi, Anadolu ve Girit içlerine ticaret yapan gemilere binerek bölgeden ayrılmaya mecbur kalmıştır. Geride kalanlar ise Bingazi, Derne gibi şehir merkezlerinde hatta iç bölgelerdeki karakollarda yaşamaya devam etmiştir. Bunlar içerisinden çok az bir kısmı ise ilk yerleştirildiği yerde hayatını sürdürmeye çalışmıştır. X. De Planhol'un tespitine göre, İtalyanlar Bingazi'yi işgal ettiklerinde (1911) burada sadece 60 Giritli aile vardır. Bu da 300 ilâ 400 arasında bir Giritli nüfusuna tekabül etmektedir. XX. yüzyılın ikinci yarısında ise bölgedeki tahmini Giritli nüfusu 350'dir (Planhol 1975, 361-362). Kısacası, başlangıçta hedeflenen miktardaki göçmen çeşitli nedenlerle bölgede iskân edilememiştir.

\section{Göçmenlerin Bölgedeki Sosyal, Kültürel ve Ekonomik Hayata Etkileri}

Bingazi ve civarında yerli ahali çoğunlukla göçebe Araplardan oluşmaktadır. Nitekim Ali Kemalî Paşa tarafından hazırlanan ıslahat layihasına göre, Bingazi 2.500, Derne 500-600, Merc 150 ve Ucla ve Calu 1000-1200 hanelik yerlerdir. Bunlardan başka dağınık birkaç zaviye etrafında ufak yerleşim noktaları bulunmaktadır. Geriye kalan halk ise konargöçerdir (BOA., ŞD. DH., Dosya No: 2325, Gömlek No: 32, 17 Cemaziyülevvel 1297/27 Nisan 1880). Ali ve Ahmet Nuri tarafindan 1883-1884 yıllarında ortaklaşa hazırlanan risalede de nüfusa dair bilgi verilirken aynı zamanda nüfusun göçebe-yerleşik olma durumu da paylaşılmıştır (bkz. Tablo 1).

Tablo 1: Ali ve Ahmet Nuri'nin Kaleme Aldığı 1883-1884 Tarihli Risalede Bingazi'nin Nüfusu (Ali ve Ahmed Nuri 1301, 35)

\begin{tabular}{|c|c|c|c|c|}
\hline Yer & $\begin{array}{l}\text { Ali Rıza Efendi } \\
\text { İstatistik } \\
\text { Risalesine Göre } \\
\text { Nüfus }\end{array}$ & $\begin{array}{c}\text { Diğer } \\
\text { Kaynaklara } \\
\text { Göre }\end{array}$ & $\begin{array}{c}\text { Mahalli } \\
\text { Salnameye Göre } \\
\text { Meskûn ve } \\
\text { Göçebe Durumu }\end{array}$ & $\begin{array}{c}\text { Bu Bilgiler } \\
\text { Dairesinde } \\
\text { Tahmini } \\
\text { Nüfus }\end{array}$ \\
\hline Bingazi Şehri & 11.900 & \multirow{6}{*}{$\begin{array}{c}\text { Bingazi } \\
\text { Sancağı genel } \\
\text { nüfusu Dr. } \\
\text { Nahtıgal'a göre } \\
\text { 302.000, İtalya } \\
\text { Ticaret Şirketi } \\
\text { layihasında } \\
\text { 246.200'dür. }\end{array}$} & Meskûn & 13.000 \\
\hline $\begin{array}{c}\text { Avâkir } \\
\text { Nahiyeleri }\end{array}$ & 9.220 & & $\begin{array}{l}\text { 3/2 Meskûn } \\
\text { 3/1 Göçebe }\end{array}$ & 10.000 \\
\hline $\begin{array}{c}\text { Cidabiye ve } \\
\text { Berka }\end{array}$ & 39.680 & & Göçebe & 50.000 \\
\hline Merc ve Derse & 28.400 & & $\begin{array}{l}\text { 10/1'i Meskûn } \\
\text { 10/9'u Göçebe }\end{array}$ & 30.000 \\
\hline Berasa ve Hase & 38.800 & & Göçebe & 40.000 \\
\hline Toplam & 128.000 & & & 143.000 \\
\hline
\end{tabular}

Ali Rıza Efendi istatistiğine göre, Bingazi merkez kazası dâhilinde 128.000 nüfus bulunmaktadır. Dr. Nahtıgal'a göre kazanın genel nüfusu 302.000 iken, İtalya Ticaret Şirketi layihasında 246.200 olarak gösterilmiştir. En nihayetinde farklı verilerden hareketle merkez 
kazaya dair ortaya konulan tahmini nüfus 143.000 'dir. Ayrıca mahalli salnamedeki verilerden hareketle nüfusun göçebelik ve yerleşiklik oranı da paylaşılmıştır. Buna göre Bingazi şehrindeki nüfus yerleşik olmakla birlikte merkeze bağlı birimlerde göçebe oranı oldukça fazladır. Hatta Berasa ve Hase ile Cidabiye ve Berka mahalleri nüfusunun sadece göçebe olduğu belirtilmiştir.

1870-1881 yılları arasında Trablusgarp ve Bingazi'de görev yapan Binbaşı Abdülvahid, bölgenin coğrafi yapısı, yerli halkı ve göçebelerinin durumları ile ilgili gözlemlerde bulunmuştur. Trablusgarp ahalisinin ehl-i beled ve urban, yani yerleşik ve göçebe olarak iki kısma ayrıldığını belirtmiştir. Ehl-i beled'in miktar bakımından meskenleri belli ise de urbanın bir yerde sakin olmadığını, hayvanlarını nerede doyurabiliyorsa oraya göçebe olarak yerleştiklerini ifade etmiştir. Halkın göçebe olmasından dolayı bazı yerlerde üretimin sağlamadığına işaret etmiştir. Örneğin Huhan kasabası hakkında bilgi verirken, "arazisi çok verimli olmakla birlikte ahalisi bedevi olmasından dolayı sanayi gelişmemiş, meyve ve sebze bahçeleri vasat bir halde kalmıştır" (Binbaşı Abdülvahid 2020, 46 ve 52) demiştir. Aynı şekilde, Girit göçmenlerinin geldiği dönemde bölge idaresiyle yapılan yazışmalarda da ahaliden "gayretsiz ve vahşi âdemler” (BOA., MVL., Dosya No: 762, Gömlek No: 37, Gurre-i Zilkade 1278/May1s 1862) olarak bahsedilmiştir.

Bu özellikleri dolayısıyla yerli ahali ile Girit’ten gelen göçmenler arasında sosyal, ekonomik ve kültürel anlamda büyük farklılıklar vardır. Zira Girit, dünyanın en büyük uygarlıklarından biri olarak kabul edilen Minos Uygarlı̆̆ı'na ev sahipliği yapmış ve kalıntıları halen dimdik ayakta duran, doğanın, yeşilin, mavinin her tonunu topraklarında barındıran (Şakar 2019, 19), zeytin ağaçları ve bağlarla kuşatılmış, Akdeniz'in ortasında önemli bir adadır. Girit kültürü de tamamen orijinal bir özellik göstermektedir. İçinde, eski dönemlerden Minos'un yanı sıra Miken, Roma, Hellen, Bizans ve biraz da Arap kültürü barındırmaktadır. Ortaçağlar ve hemen sonrasında, bu kadim kültürün üstüne kalın bir Venedik kültürü eklenmiştir. Bu senteze son olarak da Osmanlı kültürü katılmıştır. Nihayetinde bütün bunlar Akdeniz kültürü ile birleşip bir Girit kültürü oluşturmuştur (Adiyeke \& Adıyeke 2021, IX). Yerleşimcisi olan Giritliler de Avrupa ile etkileşim içerisinde olan bu adada pek çok imkâna sahip olmuşlardır. Bağı, bahçesi, zeytinlikleriyle öne çıkan adada refah içerisinde yaşamışlardır. Zeytin ve zeytinyağı imalatı, bağc1lık, hayvancılık, peynir ve yağ üretimi, buğday, arpa, sebze ve meyve yetiştirmişlerdir (Gökaçtı 2010, 55). Fakat göçe mecbur edildikleri çalkantılı dönemde bu sahip oldukları varlıklarından mahrum kalmışlar ve taşıyabildikleri kadar malzemeyi yanlarına alıp yeni bir hayata yelken açmışlardır. Venizelos, Ege Bölgesi'nde yerleşen Giritli Müslümanlar hakkında bilgi verirken, onların durumlarına dair özetle şu ifadelere yer vermiştir:

“İzmir'e bir günlük uzaklıkta olan Söke ve Selçuk'ta çok sayıda Girit Müslümanıyla karşılaşmak mümkündür. Fakat Giritli Müslümanlar çok kötü durumdadır. Güzel adasında zeytin ağaçları ve bağlar ile kuşatılmış doğayla iç içe yaşlyordu. Anadolu'da alışık olduğu yaşamı sürdürmesi zordu. Diğer taraftan Girit'ten göç etmenin zararları da vardl. Zenginlik kaynă̆ı olan mülklerini satmak zorunda kalmışlardı" (Mitçotakis 1992, 233; Adıyeke \& Adıyeke 2021, 356).

İçlerinden bir kısmı dünyanın geri kalmış bir coğrafyasında, Osmanlı'nın denizaşırı bir bölgesinde tekrar hayatlarını kazanma mücadelesine girişmiştir. Her ne kadar devletin içinde bulunduğu siyasi ve ekonomik sıkıntılar nedeniyle bölgede istenilen sayıda göçmenin iskân edilmesi mümkün olmamışsa da, yine de burada bir şekilde tutunmayı başaran ve yaşamını devam ettiren az sayıda göçmenin birtakım farklılıklar ortaya çıkardığı da görülmektedir. Başlangıçta bölgeye uyum sağlamakta zorlanmışlarsa da bir zaman sonra sosyal, ekonomik, 
kültürel alanlarda önemli gelişmelere vesile olmuşlardır.

Girit’ten gelen göçmenler, adanın köklü medeniyeti dolayısıyla, yaşayış biçimleri, yöresel örf ve adetleri, yemekleri ve giyim kuşamlarıyla farklı bir görüntüye sahip olmuşlardır. Bu nedenledir ki ilk gelişlerinde yerli halkı etkilemişler ve hatta Avrupa asıllı bir toplum gibi görülmüşlerdir. Nitekim 1908 yılında Bingazi'de bulunan N. Slousch, yerli halkın göçmenlerden etkilendiğine değinirken, Avrupalı gibi giyinip Rumca konuşan bu yeni insanlarda Rumîleri görüp, onları böyle kabul ettiklerini belirtmiştir (Slousch 1908, 152). Dolayısıyla bu insanlar, yaşam biçimleriyle, konuşmalarıyla, giyimleriyle bulundukları yerde bir farklılık yaratmışlar ve bu durumları zamanla kabul de görmüştür.

Bölgede tutunmayı başaran göçmenler, bir zaman sonra yerli ahaliyle yakın ilişkiler kurmaya başlamışlardır. Nitekim 1897 yılı öncesinde adadan ayrılıp doğrudan Bingazi’ye gelen Giritli göçmen kızları ile yerli ahaliden erkekler arasında evlilik akdinin gerçekleştiği görülmektedir. Bununla ilgili olarak 22 Şubat 1899 tarihinde Göçmen Komisyonu'na sunulan bir arzuhalde, 2.000 kadar Giritlinin 15-20 y1l önce (1880'li yıllar) adadan ayrılarak Trablusgarp, Bingazi ve Derne cihetlerine gittikleri belirtilmiştir. Burada ticaret ile meşgul olan Giritliler, zamanla yerli ahaliyle de evlenerek aile kurmuşlar ve adaya geri dönmemişlerdir. İçlerinden bazıları İzmir ve Rodos Adası'na göç ederken büyük bir kısmı Bingazi ve Derne'de kalmıştır (BOA., DH. MHC., Dosya No: 16, Gömlek No: 22, 10 Şubat 1314/22 Şubat 1899). 1870-80'li yıllarda gelenlerle ilgili Binbaşı Abdülvahid de bilgi vermiştir. Bu yıllarda özellikle Girit ve Malta taraflarından pek çok göç alındığına ve bu göçlerin bölgede değişim yönünden önemli etkisi olduğuna işaret etmiştir (Binbaşı Abdülvahid 2020, 53).

Libya'da yaşayan ve Girit kökenli bir mühendis olan Ahmet Astrakanaki de elde ettiği veriler doğrultusunda bölgeye yaşanan göçü değerlendirirken, göçün ilk aşamasını, 1860-1890 yılları arasında adadan hareketle doğrudan Bingazi'ye gerçekleşen göçlerin oluşturduğunu ve bu dönemde gelen Giritlilerin y1llar içerisinde tamamen asimile olup, öz dilleri ve adetlerini kaybettiklerini, bunda özellikle yerli Araplarla yapılan evliliklerin rol oynadığını belirtmiştir. Göçün ikinci aşamasını ise, 1896-1900 yılları arasında gerçekleşen göçlerin oluşturduğunu ve bu dönemde gelen Giritlilerin, asimile olmamak için ciddi bir gayret içerisinde olduklarını, büyük çabalar göstererek Giritliliklerini korumayı bir şekilde de olsa başardıklarını belirtmiştir (Astrakanaki 2014, 8-9).

Giritli kadınların yerli ahaliden erkeklerle evlenmeleri sonucunda bir tarafı Giritli, bir tarafı Bingazili veya Derneli olan melez aileler ortaya çıkmıştır. Nitekim araştırmacı yazar Orhan Koloğlu'nun babası Sadullah Koloğlu da Giritli bir annenin ve Derneli bir babanın çocuğu olarak 1884 yılında dünyaya gelmiştir. Babası Derne'de yă̆ ticareti ile uğraşan Hacı Mebruk Efendi, Annesi ise Girit'ten sürülüp Bingazi'ye sığınan Zeynep Hanım'dır (Koloğlu 2001, 7 ve 10-11). Sadullah Koloğlu, anılarında, Derneli erkeklerin en çok ilgilendikleri konunun Giritli kadınlar olduğunu belirtmiştir: "Nasıl bütün İslam âleminde İstanbul'un saraylı kadınları ünlüyse, bizim orada da varsa yoksa Giritlilerdi." demiştir. Giritli kadınların bölgede ün salmalarının yanı sıra bilgileri, kültürleri ve idarecilikleriyle yerli kadınların sadeliklerini aşarak aileler içinde yeni ufukların açılmasına sebep olduklarını (Koloğlu 2001, 11) ifade etmiştir.

Bingazi'ye gelen Giritli göçmenler arasında farklı meslekleri icra eden insanlar da vardır. Nitekim 181 göçmene ait bilgilerin yer aldığı bir arşiv vesikasında, aile reisinin adı, mesleği, geldiği yer ve tarihi, nüfusu gibi detaylı verilere ulaşmak mümkündür. Bingazi merkezinde geçici olarak bulunan bu göçmenlerin özellikle esnaf sınıfindan oldukları görülmektedir. İçerisinde kunduracl, kasap, kahveci, bakkal, teymurcı (demirci), terzi gibi meslekleri icra 
edenler vardır. Bir kısmı da çiftçi olduğunu belirtmiştir. Ayrıca göçmenlere bölgede kalıp kalmama niyetleri sorulduğunda, bir kısmı yeni kurulacak köylerde, bir kısmı da Bingazi merkezinde kalmak arzusunda olduğunu beyan etmiştir. Aralarında Girit'e dönmek niyetinde olanlar da vardır (BOA, DH. MKT. PRK., Dosya No: 2197, Gömlek No: 137, 24 Temmuz 1315/5 Ağustos 1899). Dolayısıyla meslek sahibi bu göçmenlerin, Bingazi kasabasında veya yeni kurulacak köylerde iskân edilmeleriyle birlikte bölge ekonomisine katkı sağlayacağı muhakkaktır. Daha önce görülmeyen meslek gruplarının bölgede faaliyet göstermeye başlamasının, aynı zamanda yerli ahaliye de yeni iş sahaları açması bakımından önemli olduğu düşünülmektedir. Osmanlı hâkimiyetinin sona erdiği dönemde Bingazi'den İzmir'e yapılan göçün şahitlerinden birisi yaşananları anlatırken, “...Libyalıların yoğunlaştı̆̆ Eşref Paşa'da istenmeyen olumsuz hiçbir olay yaşanmadl. Herkes orada tıpkl kendi vatanında yaptığ gibi hayatını kazanmaya çalıştı. Libya'da marangoz olan, burada marangozluk, bakkal olan da bakkalliğını sürdürdü..." (Muhammed el Usta 1983, 28.'den aktaran Kurşun 2013, 4) demiştir. Dolayısıyla Giritli göçmenler, Bingazi'de mesleklerini icra etmişler, hatta daha sonra göç ettikleri İzmir'de de bunu devam ettirmişlerdir.

Göçmenler bölgeye ulaştıklarında barınma sorunuyla karşı karşıya kalmışlardır. Bingazi ve civarında tespit edilen iskân mahallerinde mesken inşasının gelişmemiş olduğu, halkın çoğunluğunun göçer halde yaşadığı, hatta mağaraların yerleşim yeri olarak kullanıldığı görülmüştür. Dolayısıyla mesken inşasına kadar göçmenlerin de mağaralarda geçici olarak yerleştirilmeleri söz konusu olmuştur. Örneğin, 1899 yılı Eylül ayında Bingazi merkezinde bulunan 500 hane göçmenden 200 hanesinin, memurların keşifleri doğrultusunda Susa'da inşa edilecek meskenlerde ve mevcut olan 60 kadar mağarada yerleştirilerek kıştan korunmaları amaçlanmıştır. Yine, 50 hanenin de Ayn-ı Şehhat'taki mağaralara geçici olarak yerleştirilmesi planlanmıştır. Yine, Bingazi'ye 12 saat mesafede bulunan Tulmayta mevkiinde 150 kadar mağara mevcut olduğu ve kış mevsimi geçinceye kadar 250 hane göçmenin burada iskân edilebileceği belirtilmiştir (BOA., A. MKT. MHM., Dosya No: 506, Gömlek No: 11, 14 Eylül 1315/26 Eylül 1899).

Göçmenlerin iskânı için Bingazi ve Derne'ye bağlı Butraba, Cuybiye, Gerse, Kuyfiye, Huybiye, Karyanoz gibi mevkiler tespit edilmiştir. Fakat bu yerlerle ilgili hazırlanan raporda, $b u$ iskân mahallerinin, memleketin diğer mahalleri ile mukayese edilemeyecek durumda olduğu, ahalisinin de gayrimeskûn olarak göçer halde yaşadığı belirtilmiştir. Dolayısıyla Susa'da toplanmış olan göçmenlerin o civarda yerleştirilmelerine bir imkân görülememiş ve onların kış mevsimini hoşnut geçirebilmeleri için Ayn-ı Şehhat'taki mağaralarda 50 hane, Tulmayta'da ikamete elverişli bulunan mağaralarda 75 hane, Susa'da şimdiye kadar yapılan meskenler ile burada ikamete elverişli mağaralarda 250 hane ve Derne'deki bina ve meskenlerde 140 hane taksim edilerek yerleştirilmiştir. Kalan kısmı da Bingazi’ye götürülerek uygun mahallere ikame edilmiştir (BOA., A. MKT. MHM., Dosya No: 506, Gömlek No: 11, 15 Teşrinievvel 1315/27 Ekim 1899). Dolayısıyla göçmenlerin barınmaları konusu, mesken eksikliğinden veya inşasının gecikmesinden dolayı büyük bir sorun teşkil etmiştir. İlk etapta mağaralar iskân yerleri olarak değerlendirilmiştir.

Mesken ihtiyacını karşılamak için mevcut imkânlar dâhilinde inşa çalışmaları yürütülmüştür. Tayin edilen memurlar marifetiyle iskâna uygun alanlar tespit edilerek mesken inşasına çalışılmıştır. Özellikle Susa ve Ayn-ı Şehhat mevkilerinde çalışmaların yoğunlaştığ1 ve birtakım binaların inşasına başlandığı görülmektedir. Nitekim Ali Tevfik, H.1318/M.1900 tarihli "Memâlik-i Osmaniyye Coğrafyası" eserinde, Ayn-ı Şehhat'da Girit göçmenlerinin yerleşmiş olduğunu ve aynı zamanda bu kasabada cami, mektep ve hamam inşa edilmeye başlandığını belirtmiştir (Ali Tevfik 1318, 474). Dolayısıyla sadece mesken inşası değil, aynı zamanda 
eğitim, ibadet ihtiyaçları için de iskân çalışmalarının yürütüldüğü anlaşılmaktadır. Ayrıca, Şehhat'ta yer alan Giritli ailelerin, Trablusgarp Savaşı esnasında da burada yaşamlarını sürdürdükleri tespit edilmektedir. Nitekim 1912 yılı Mayıs ayında yaralılar için teşkil edilen Şehhat Nekahethanesi'nde aşç1lık görevini Giritli Ali Ağa ile eşi yapmıştır (Dirim 1956, 156). Yine, savaşa gönüllü olarak katılan Dr. Yüzbaşı Hüseyin Hüsnü Bey de 1880 Girit Hanya doğumlu olup, İstanbul'dan 31 Ekim 1911'de yola çıkarak Tobruk Karargâhına ulaşmıştır. 20 Mayıs 1912'de resmi açılışı yapılan Şehhat Nekahet Hastanesi'nde doktorluk yapmış, 1912 yılı Temmuz ayı sonunda sağlı sorunları sebebiyle Bingazi'den ayrılmıştır (29 Ekim 1911-23 Temmuz 1912 tarihleri arasında tuttuğu günlüğü ile ilgili olarak bkz. Değer 1998). Mustafa Kemal Bey de 3 Haziran 1912 tarihinde Şehhat Nekahethanesi'ne gelmiş, beraberinde bulunan; Fehmi Efendi, Süreyya Bey, Teğmen Nuri Efendi ve 12 askerle birlikte Susa'ya gitmek üzere ayrılmış, daha sonra 10 Haziran 1912'de yeniden gelerek 25 Haziran sabahına kadar burada kalarak tedavi görmüştür (Değer 1998, 17).

İskân çalışmalarının yürütüldüğü Susa'da da mesken inşasının sağlandığı görülmektedir. Nitekim 1904 yılında Bingazi coğrafyasını gezen İngiliz arkeolog David George Hogarth, Giritli ailelerin kıyı kesimlerinin belli noktalarına nakledildiğini ve onlara evler tahsis edildiğini belirtmiştir. Bir zamanlar Apollonia antik kentinin bulunduğu eski Bingazi (Cyrene) limanı olan Susa'da (Marsa Susa) 100 kadar göçmen ailenin; Ayn-ı Şehhat'ta da bir avuç asker ile birlikte 60 kadar ailenin olduğunu yazmıştır (Hogarth, “A Visit to Cyrene”, 16 Ağustos 1904). 1908 yılında burayı ziyaret eden ve Giritli aileler ile karşılaşan N. Slousch ise, Bingazi'nin (Cyrene) eski limanı olan Susa'da bir Girit kolonisinin oluştuğunu belirtmiştir. 52 Giritli aile, Apollonia eski şehrinin hemen hemen bütün sahasına yayılmıştır. Susa meydanındaki küçük bir Türk kahvehanesi, bölge sakinlerinin yaşayış tarzı ve hükümetçe yaptırılan küçük evlerin temiz görünüşü, Susa'ya küçük bir Türk-Yunan şehri görüntüsü vermiştir. Ayrıca, Türk yetkililerce Giritlilere Türkçeyi benimsetmek için okul açılmıştır (Slousch 1908, 153). Hatta İngiliz konsolosu Alvarez Scotti, 1899 yılı Ağustos ayında Ayn-ı Şehhat'a gelen göçmenlerin eğitimleri için 1.600 Türkçe kitap ve başka malzemeler verildiğini belirtmiştir (TNA, PRO, FO, 101/89, 18 Eylül 1899; Lorenz 2021, 101). Fakat bölge halkı Rumca konuşmaya devam etmiştir (Slousch 1908, 153). Dolayısıyla inşa ettikleri bu yerleşim merkezinde, kendi kimliklerini, dillerini korumaya çalışmışlardır.

XX. yüzyılın ikinci yarısında Susa mevkiinde yaşayan tahmini Giritli göçmen sayısı 350'dir. Xavier De Planhol'un yaptığı araştırmaya göre bu 350 kişi, komşu kabilelerden gelen Arap nüfusun yavaş yavaş biriktiği Susa'nın şimdiki nüfusunun onda biri kadardır. Dolayısıyla bölgedeki mevcut Giritlilerin bu direnişi, sabit bir göç dalgasının devamlılığına neden olarak artan nüfusu da dengelemiştir (Planhol 1975, 361-362).

N. Slousch ise, Bingazi (Cyrene) harabelerinde ve mağaralarında da 75 Giritli ailenin yaşadığını tespit etmiştir. Hatta bu ailelerden ikisiyle de karşılaşmış ve dolayısıyla onların hayat şartlarına yakından şahitlik etmiştir. Göçmenlerin özellikle bölgede geleceğin şehirlerinin çekirdeğini oluşturduğuna dikkat çekmiştir (Slousch 1908, 152). Dolayısıyla bölgede kalan göçmenlerden önemli bir kısmı, harabe alanlarda ve mağaralarda hayatlarını devam ettirirken aynı zamanda yeni gelişmelere de ön ayak olmuşlardır.

Bingazi ve çevresindeki bu mimari değişimin aslında 1870-1881 yılları arasında yaşanan göçlerle başladığı söylenebilir. Nitekim bu yıllarda Bingazi'de bulunan Binbaşı Abdülvahid, bölgenin Girit ve Malta'dan çok göç aldığına işaret etmiş ve önceden pek mamur bir yer olmayan Bingazi'nin yeni tarz binalarla imar edilmekte ve günden güne gelişmekte olduğunu (Binbaşı Abdülvahid 2020, 53) belirtmiştir. Yine Derne kasabasını ziyaretinde, Girit Adası'ndan 
gelip yerleşenler sayesinde kasabanın eski görünümünün yenilendiğini, çoğu yerlerine büyük ve yeni tarz binalar yapıldığını ve günden güne gelişmekte olduğunu (Binbaşı Abdülvahid 2020, 54) görmüş̧ür. Dolayısıyla bölgedeki mimari değişimin temellerinin 15-20 y1l öncesinde adadan yapılan göçlerle atıldığı, daha sonra gelenlerle de geliştirildiği söylenebilir. Nitekim Bingazi'deki İngiliz konsolosu da göçmenlerin, yerleşim yerlerini ve kıyı şeridine giden yolu daha da iyileştirmek için eski altyapıyı restore ettiklerine değinmiş ve bu anlamda en önemli gelişmenin ise yetenekli Giritli Müslüman mühendislerin Susa'daki antik Roma su kemerini tamir etmeleri olduğunu belirtmiştir (TNA, PRO, FO, 101/89, 18 Eylül 1899; Lorenz 2021, $101)$.

Girit'in üç büyük sancağı olan Kandiye, Hanya ve Resmo'da Osmanlı idaresiyle birlikte yaygın olarak Bektaşi tekkeleri ve son devirlerde de Mevlevi tekkeleri varlığını hissettirmiştir (Kara 2008, 78-79). Girit göçmenleri içerisinde Bektaşi tarikatına mensup bir gurubun, Girit’ten Bingazi'ye geldikten kısa bir süre sonra burada da kendi Bektaşi tekkesini kurmaya çalıştığı görülmektedir. Hatta şeyhleri Hasan Baba'yı, Hanya'dan ayrılıp Bingazi'ye gelmesi ve Bektaşi tekkelerini yönetmesi için davet etmişlerdir. Fakat Hasan Baba, Girit’ten ayrılamadan önce vefat etmiştir. Böylece Giritliler, şeyhleri olmadan Bektaşi geleneğini sürdürmeye çalışmışlardır (Bilgi için bkz. Hasluck 2003).

Bingazi coğrafyasında yaşayan Giritli aileler, dünyanın geri kalmış bölgesinde ekonomik açıdan da birtakım farklılıkları ortaya çıkarmışlardır. Devlet, arpa, buğday, fasulye, pamuk, mısır ve soğan yetiştirmeleri için göçmen ailelere arazi ve tohum yardımında bulunmuştur (Gregory 1916, 326). Onlar da bu yardımlarla birlikte arazileri işlemeye çalışmışlardır. Nitekim 1908 y1lında bölgeyi ziyaret eden N. Slousch'un tespitine göre, 52 Giritli aile, Apollonia eski şehrinin (180 hektar/1.800.000 $\left.\mathrm{m}^{2}\right)$ hemen hemen bütün sahasına yayılarak asma zeytin ve buğday yetiştirmişlerdir. Derne, Bingazi ve Meray'a kadar olan bölgede Araplara tarım örneği veren bahçelikler oluşturmuşlardır (Slousch 1908, 152). Bu üretim faaliyetleriyle Bingazi kıyı şeridinin ve hinterlandının dönüşümünde aktif bir rol oynamışlardır (Lorenz 2021, 90). Tarımla uğraşanların dışında kalanlar ise sanatkâr ve küçük memur olarak hayatlarını devam ettirmişlerdir (Slousch 1908, 152).

Bingazi'deki tarımsal alanların kullanımı ve elde edilen ürünler ile ilgili olarak değişimi görmek adına, 1897 ve 1909 yıllarına ait istatistiki verilere bakılabilir. Nitekim bu yıllar, göçmenlerin bölgeye geldikleri ve yerleşik hayata geçip üretim yaptıkları yılları kapsaması bakımından önemlidir. 1897 yılında Bingazi'de tahılların ekiliş alanı, 54.300 dönüm buğday ve 550.000 dönüm arpa olmak üzere toplam 604.300 dönümdür. Bu alanlardan 3.486 ton buğday ve 35.053 ton arpa elde edilmiştir. 1909 yılında tahılların ekiliş alanları ise, 174.900 dönüm buğday, 1.229.660 dönüm arpa, 800 dönüm misır ve 90 dönüm diğer tahillar olmak üzere 1.405.450 dönüme ulaşmıştır. Bu ekili alanlardan 10.855 ton buğday, 79.003 ton arpa, 270 ton misır ve 3 ton diğer tahıllar elde edilmiştir. Dolayısıyla buğday ve arpa ekim alanında ve elde edilen üründe önemli bir artış meydana gelmekle birlikte ayrıca 1897'den farklı olarak mısır ve diğer tahıllar da ekilmiştir. Yine, 1909 yılında baklagillerin ve köklü bitkilerin ekildiği görülmektedir. Bu anlamda, 5 dönüm fasulye, 3 dönüm mercimek, 3 dönüm patates ekim alanları bulunmaktadır. Bunlar içerisinden 1 ton fasulye ve 3 ton patates elde edilmiştir (Güran 2017, 173-174, 190-193 ve 199-201).

Bingazi'de zeytin ve zeytinyağı üretimi konusunda 1897 yılına ait veri olmasa da 1909 y1lında 364 bin zeytin ağacının olduğu kaydedilmiştir. Bundan 4.274 ton zeytin elde edilmiş ve değeri 4.660 bin kuruştur. Ayrıca 570 ton zeytinyağı elde edilmiş ve bunun da değeri 2.710 bin kuruştur. Bağcılık alanında yapılan üretimle ilgili olarak 1909 yılı verilerine ulaşılabilmektedir. 
Nitekim bu yılda 50 dönüm bağlık alan bulunmaktadır. Bundan 171 ton üzüm elde edilmiş ve değeri 111 bin kuruştur. Aynı yılda meyve olarak da 1 ton elma, 83 ton incir, 1 ton badem ve 2.766 ton hurma üretilmiştir (Güran 2017, 215, 217, 219 ve 221). Netice itibariyle hem ekili alan ve üretim artışında hem de 1909 yılında görülen ürün çeşitliliğinde, kısmen de olsa göçmenlerin de etkisinin olduğu düşünülmektedir.

Giritli aileler, yetiştirdikleri ürünlerle hem tarıma katkı sağlamışlar hem de bölgede teşkil ettikleri küçük Türk garnizonuna erzak temin etmişlerdir. Bunun yanı sıra Araplar için de kumaş imal etmişlerdir. Bu anlamda Susa'ya gelen gemilerden faydalanmışlardır (Slousch 1908, 152153). Zira adada yaşadıkları dönemde birçok Giritli evinde, Giritli söyleyişiyle, argastiri denilen basit bir dokuma tezgâhı yer almıştır. Bu tezgâhta, kırpılmış rengârenk bez şeritlerden veya boyalı yün ipliğinden değişik desenli kilimler, çulalar (paspaslık çula) ve daha pek çok çeşit desende dokuma işleri üretilmiştir. Dokunan kumaşlardan ayakkabı da imal edilmiştir (Şakar 2019, 33-34). Dolayısıyla Giritliler bu hünerlerini, göç ettikleri yerlerde de devam ettirmişler ve o yerlere, kültürel ve ekonomik anlamda bir zenginlik katmışlardır.

Giritli göçmenlerin, devletin başlangıçta hedeflediği askeri gücün artırılmasına yönelik de hizmet ettikleri, böylelikle bölgede güvenliğin artırılması anlamında önemli bir katk1 sağladıkları anlaşılmaktadır. Nitekim Lorenz, yapmış olduğu araştırmada, Osmanlı Hükümeti'nin, Giritli Müslümanları yerel bir güvenlik unsuru olarak da değerlendirdiğini belirtmiştir. Tarımsal yerleşimleri koruyan silahlı Osmanlı birliklerine ek olarak, Giritli Müslümanlar da Bingazi'de Osmanlı ordusuna yardımcı destek kuvvet sağlamışlardır. Kabile saldırılarına ve Avrupa'nın Bingazi'yi işgaline karşı bir güvenlik unsuru oluşturmuşlardır (Lorenz 2021, 102).

Ayn-ı Şehhat, Marsa Susa ve Tobruk'taki göçmen yerleşimleri, Osmanlı savunma kaleleri olarak hizmet vermiştir. 1899'da Bingazi valisi, sahil şeridindeki Bomba ve Tobruk'ta Osmanlı egemenliğini simgeleyen bayrağın her gün çekilmesini emretmiş̧ir. Ayrıca, bu bölgelere yönelik herhangi bir tehdide karşı ilave takviye sağlamak için her iki bölgede konuşlu Osmanlı piyade sayısı artırılmıştır. Silahlı Giritli Müslüman yerleşimcilerin nöbetçi olması tarımsal yerleşim yerlerinde tanıdık bir manzara haline gelmiştir. Hatta Giritli Müslüman bir göçmenin Derne valiliğine atanması, bölgede Giritli Müslümanlardan oluşan yardımcı kuvvetlerin iyi silahlanmasını ve yerel Osmanlı piyadeleri tarafından da desteklenmesini sağlamıştır (Lorenz 2021, 103-104).

Bütün bu gelişmeler yanında gerek iskân sürecinin ilk aşamasında gerekse iskândan sonraki yıllarda yerli ahalinin sebepsiz yere göçmenleri taciz etmeleri de söz konusu olmuştur. Nitekim göçmenlerin yetiştirdikleri ürünlerin ve hayvanların çevredeki göçebe aşiretler tarafindan yağmalandığı, kendilerinin de darp edildiği dönemler yaşanmıştır. Buna, $S u s a$ 'da iskân edilmiş olan Giritli göçmenlerden Hasan ve ailesinin uğramış olduğu saldırılar örnek verilebilir. Nitekim idareye sunmuş oldukları arzuhalde, büyük emek sarf ederek işledikleri bahçelerin ve ürünlerin, yetiştirdikleri hayvanların çevredeki göçebe aşiretler tarafından yağmalandığını ve kendilerinin de darp edildiğini belirtmişlerdir (BOA., DH. MKT., Dosya No: 2664, Gömlek No: 40, 6 Teşrinisani 1324/19 Kasım 1908). Dolayısıyla yaşanan bu hadiseler, göçmenler arasında bir huzursuzluk yaratmakla birlikte bölgeden ayrılmalarında da önemli rol oynamıştır. Netice itibariyle yerli ahalinin göçmenleri benimsemesi, göçmenlerin yerli ahaliye uyum sağlaması kolay olmamıştır. Nitekim bu ilk süreçle ilgili olarak N. Slousch, "Giritliler Avrupalı olarak yaşadıkları güzel adalarını özlemişlerdir. Her ne olursa olsun Giritlilerin göçünün Bingazi'de yoğunlaşmasını beklememek gerekiyordu" (Slousch 1908, 153) demiştir.

Bingazi mebusu Ömer Mansur, 16 Temmuz 1909 tarihli meclis oturumunda, "Girit, bütün Akdeniz'in, Afrika-yı Osmanî’nin anahtarıdır, korumalıyız... Eğer Girit gidecek olursa bütün 
memalik-i Osmaniye parçalanacaktır.”(Koloğlu 2003, XX) demiş ve bu coğrafyada var olmak için Girit'in çok önemli bir yere sahip olduğuna işaret etmiştir. Girit sorunundan bahsederken açıkçası kendi bölgesinin de aynı akıbete uğraması endişesini taşımıştır. Fakat bu önemli ada, devletin içinde bulunduğu siyasi, ekonomik sıkıntılar nedeniyle elde tutulamamıştır. Adadaki hâkimiyetin fiilen sona ermesi büyük bir kayıp olmakla birlikte, adadan ayrılmak zorunda kalan ahalinin farklı yerlerde ortaya çıkardığı gelişme ise ayrı bir durum arz etmiştir. Nitekim burada da ele alındığı üzere bir kısım ahali, Bingazi’de önemli gelişmelere öncülük etmiştir.

Trablusgarp ve Bingazi, Osmanlı Devleti için stratejik açıdan son derece önemli yerler olmuştur. Nitekim Girit'teki hâkimiyetin fiilen sona ermesinden (1897) sonra, Akdeniz sahillerinde etkili olabilmek için bu son Afrika topraklarının elde tutulması daha önemli hale gelmiştir. Bu öneme dair Sebîlü'r-reşâd' da yer alan bir yazıda, "Trablusgarp gerek Osmanl, gerekse Âlem-i İslâmiyet için fevkalade mühim bir merkezdir. Afrika-yı Vüstâ [Orta Afrika] içinde medeniyet ve efkâr-ı İslâmiye'nin [İslam Düşüncesinin] intişârı (yayılması) emrinde yegâne bir kapı, bir pencere olarak kalmış idi." ("Trablusgarp'ın Müslümanlarca Ehemmiyeti ve İtalya'nın Afrika'da Müslümanları Boğmak Emeli”, Sebîlü'r-reşâd, 28 Mart 1912, 69; Kavas 2005, 49) şeklinde bir değerlendirmede bulunulmuştur. Dolayısıyla bu önemli yerin savunulması için dönemin en genç subayları cepheye koşmuşlardır. Dr. Yüzbaşı Hüseyin Hüsnü Bey'in günlüğünde de aktardığı gibi, Mısır ve Tunus üzerinden Trablusgarp'a ulaşmaya çalışan gönüllü Türk subaylarının pek çoğu gerçek kimliklerini gizleyerek sahte isim ve kimlikler kullanmışlardır. Giden gönüllülerin içinde dönemin Berlin Ateşesi Binbaşı Enver Bey, Paris Elçiliği Ateşemiliteri Fethi Bey (Okyar), Rauf Bey (Orbay), Ömer Fevzi Bey (Mardini) Bey ve Kurmay Yüzbaşı Mustafa Kemal (Atatürk) gibi önemli isimler vardır (Değer 1998, 6). Sonuç itibariyle gönüllü subaylar, yerli halkla birlikte hareket ederek yüz bin kişilik İtalyan ordusuna karş1 önemli bir direniş göstermişlerdir. Zira 1 Mayıs 1911 tarihli kayıtlara göre Trablusgarp’ta bulunan personel say1s1 2.880, Bingazi'de bulunan personel sayıs1 ise 1.200'dür. Trablusgarp ve Bingazi'de bulunan askerlere ilaveten 22 subay ile 250-300 askerden oluşan bir de jandarma teşkilatı bulunmaktadır. Dolayısıyla mücadelenin esas insan gücünü yerli kabileler oluşturmuştur. Düzensiz ve silahsız bir halde bulunan yerli halk, savaşa inanmış ve iyi yönetilmiştir (Ertuna 1981, 60-61; İlhan 1990, 40). Fakat bir süre sonra Afrika'daki son toprak parçasının kurtarılması ümidinin tükenmesiyle birlikte Osmanlı Hükümeti, İtalya ile barış görüşmelerine başlamıştır. Yapılan görüşmeler neticesinde 18 Ekim 1912 tarihinde Uşi Antlaşması imzalanmış ve bölge İtalya'ya bırakılmıştır (Trablusgarp Savaşı konusunda detaylı bilgi için bkz. Beydilli 2016, 613-616).

Trablusgarp ve Bingazi'de İtalyan işgalinin (1911) gerçekleşmesi ile birlikte bölgede bulunan Girit göçmenleri de tekrar zor günler geçirmişlerdir. Girit’te yaşadıkları baskı ve zulme bir kez daha maruz kalmışlardır. Trablusgarp ve Bingazi'de İtalyan baskıları her geçen gün arttıkça onlar da tekrar sığınacak yeni bir vatan arayışına girmişlerdir. Burada yaşayan Türklerin önemli bir kısmı İzmir'e göç etmeye başlamıştır. Hatta bu göç Birinci Dünya Savaşı'nın sonuna kadar da devam etmiştir. Bu dramatik göçün şahitlerinden biri olayları şöyle nakletmektedir:

'Libyal Arap muhacirler İzmir'i yurt edindi. Libya'daki adetleri ve geleneklerini İzmir'e taşıdılar. Örflerinden hiçbir şeyi değiştirmediler. Kahveler, kasaplar hepsi Libyalı. İş yeri açma ruhsatı isteyen herkese ruhsat verildi. Eski gelenler yeni gelen muhacirlere yardimcı oldu. Çoğunlukla aynı bölgede biriktiler. Bu yüzden adet ve geleneklerini terk etmediler.. Türk makamlarından da daima hesapsiz himaye ve yardım gördüler. Bu yüzden Libyalıların yoğunlaştı̆̆ı Eşref Paşa'da istenmeyen 
olumsuz hiçbir olay yaşanmadi. Herkes orada tıpkı kendi vatanında yaptığı gibi hayatını kazanmaya çalıştı. Libya'da marangoz olan, burada marangozluk, bakkal olan da bakkallı̆̆ını sürdürdü... Dügünler, törenler ve matemler hep Libya'daki gibi yapıllyordu. Klyafet, lehçe her şey aynı kalmıştı. Sadece Eşref Paşanın sinırları genişlemişti, burası adeta Trablusgarp, Bingazi ve Misrata'nın bir parçası olmuştu..." (Muhammed el Usta 1983, 28.'den aktaran Kurşun 2013, 4).

1911-1951 yılları arasında Libya artık bir İtalyan sömürgesi haline gelmiş ve ülkenin her yerinde sömürülmeye karşı bir direniş ve silahlı mücadele başlamıştır. Giritliler de bu ortamda ister istemez bölgede bulunan Arap kabilelerinin himayesi altına girmek zorunda kalmışlardır. Bu süreç, 1951 yılında egemenliklerini kazanıp Libya'da bir kraliyet yönetiminin kurulmasına kadar devam etmiştir. Bu yeni dönemde anayasanın ilan edilmesiyle birlikte Giritliler birer Libya vatandaşı olmuşlardır. Bugün Libya'nın Susa ve Şehhat kasabalarında yaşayan Giritli Müslümanların soyadları: Şerifaki, Bilalaki, Bayramaki, Tatanaki, Özmenaki, Kuyutaki, Hasanaki, Mavraki, Katsoşeraki, Kulaki, Bağaki, Sofraki, Terzelaki, Rüstemaki, Katronaki, Mehmedilaki, Kuyutaki şeklindedir (Astrakanaki 2014, 8-9).

Osmanlı Devleti, bu bölgeyi İtalyanlara bırakmak zorunda kalmışsa da hiçbir antlaşma dört yüzyıllık bir geçmişe sahip idari bir yapının köklerini kazıyamamıştır. Nitekim o dönemin önde gelen Osmanlı askerleri nasıl ki Trablusgarp'taki cephelerde İtalyanlara karşı cansiperane çarpışmışlarsa, Libya'da yaşayan Türk soylularla birlikte yerli Berberi ve Araplar da başta Kurtuluş Savaşı'nda olmak üzere Anadolu'ya kadar gelerek Millî Mücadele'ye destek olmuşlardır. Özellikle Osmanlı döneminde Libya topraklarını buradaki valilerin desteğiyle bir faaliyet alanına dönüştüren Cezayir asıllı Muhammed b. Ali es-Senûsî'nin torunlarından ve hareketin üçüncü önderi olan Ahmed Şerif, Türkiye'ye gelip buradaki Millî Mücadele'nin kazanılması için Anadolu'yu şehir şehir gezerek yaptığı konuşmalarla halkı galeyana getirmiştir (Kavas 2005, 50).

Son olarak, burada değinilmesi gereken bir husus da bir tarafı Giritli, bir tarafı Kuloğlu olan aileye mensup bazı kişilerin, yetiştikleri Libya coğrafyasına ilerde önemli hizmetlerde bulunmalarıdır. Nitekim bunlardan birisi Sadullah Koloğlu'dur. İtalyan işgaline kadar olan dönemde Sadullah Koloğlu'nun babası Derne'de Belediye Başbakanlığı'na denk düşen bir görevde yer almıştır. Babasının görevi sebebiyle İstanbul'a sultan Abdülhamid'in huzuruna gittikleri bir törende Abdülhamid ile tanışma firsatı bulmuş ve çok iyi Türkçe konuşması sebebiyle Sultan Abdülhamid tarafindan kendisinin İstanbul'da kurduğu aşiret mekteplerinde eğitim görmesi istenmiştir. Bunun üzerine 10 yaşındayken Derne'den ailesinin yanından ayrılarak geldiği İstanbul'da eğitimine başlamıştır. 18 yaşında eğitimini tamamlayan Sadullah Koloğlu, ilk olarak Bingazi Mutasarrıflığı'nda Maiyet Memurluğu'na daha sonra da Derne Nahiye Müdürlüğü'ne atanmıştır (1902-1909). 1910 tarihinde de kendisini, Libya topraklarından Anadolu'ya, Denizli'nin Buldan ilçesinin kaymakamlığına atamışlardır. 1909 ile 1938 yılları arasında çeşitli ilçelerde kaymakamlık, Bingöl ve Hakkâri'de valilik yapmıştır. Libya'da başbakan olması ise şu şekilde gelişmiştir: İkinci Dünya Savaşı sırasında İngilizler Libya'yı ele geçirmişlerdir. Bu dönemde Bingazi, Şeyh İdris Senusî (sonradan Kral olacak) yönetimindedir. Fakat bir çeşit manda yönetimi olup İngiliz komutan idare etmektedir. 1949 yılında, Birleşmiş Milletler Libya'da manda yönetiminin bitmesi ve parlamenter sisteme geçilmesi kararını almıştır. Şeyh İdris Senusî ülkeyi yönetecek kadroyu kurmakta zorlanmıştır. Bu süreçte, daha önceden tanıdıkları, çocukluğu Libya'da geçen ve Türkiye'de valilik yapmış olan Sadullah Koloğlu gündeme gelmiş ve Bingazi'de başbakan olması için davet edilmiştir. Nitekim dönemin 
Bakanlar Kurulu da bu yönde karar almış ve gitmesine izin vermiştir. Nihayetinde Şeyh İdris Senusî tarafından Türkiye'nin "Arap Kaymakam”1 Sadullah Bey, Libya Devleti'nde “Türk Başbakan” lakabıyla başbakanlığa getirilmiştir (Detaylı bilgi için bkz. Koloğlu 2001, 7-159).

23 Ocak 1950 tarihinde TBMM'nin Bakanlar Kurulu'nda alınan karar gereğince Sadullah Koloğlu Libya'ya görevlendirilmiştir (BCA, Fon No: 30-18-1-2, Kutu No: 121, Dosya No: 101, Sira No: 20, s. 1, 23 Ocak 1950). Sadullah Koloğlu'nun oğlu Orhan Koloğlu'nun belirttiğine göre, bu dönemde Libya'daki şartlar hiç iç açıcı değildir. Dolayısıyla Libyalıların, Sadullah Koloğlu'nun deneyimine ve bilgisine ihtiyaçları vardır. Orhan Koloğlu, bir röportajında, Libya'daki durum ve babasının göreviyle ilgili olarak şu ifadelere yer vermiştir:

“(...)Babam Türkiye'de kaymakamlı görevinden emekli olduktan sonra, Miras işlemleri için Libya'ya gittiği bir sırada, Babamın orada olduğunu haber alan Kral İdris, kendisini Libya'ya davet etti. Burada babamı Başbakan yaptılar. Şimdi düşünebiliyor musunuz? Burada bir garabet var. Kendilerinden kopmuş Türkiye'ye gitmiş ve uzun yıllar orada yaşayarak kendisine bir hayat kurmuş, Libya'ya çağırıyorlar, Başbakan olması için. Aslinda sebebi gayet basit, Libya meclisindeki temsilci ailelerin büyük bir kısmı Bedevi. Çöl Bedevisi. Yani Çöl Bedevisi dediğimiz zaman çölün ortasında, bin kilometre ötede kuru bir yerde yaşayan bir grup. Böyle bir grubun kültürünün olmasinı veya gelişmesini bekleyemezsiniz. Eğitimden vesaire bahsetmek zaten imkânsız. Babamsa Ingilizce biliyor, Arapça biliyor, Türkçe biliyor. Yani Arap’ı da Türk'ü de Libyalı 'y da çok iyi tanıyor, biliyor ve onlarla konuşabiliyor. Ha birde müthiş bir şekilde Kur'an-ı Kerim'in tamamını biliyor. Hal böyle olunca aslında babamı oraya çağırmış olmaları gayet mantıkî. Hepsinin üstünde. Hem Ingilizlerle hem de Araplarla iletişim kurabiliyor. Ben bir 10 ay kadar Libya'da babamın yanında bulundum. Meclisteki nutuklarını dinledim. Bakın, Bedevi babamı anlamıyordu. Arapça 'yı çok iyi konuşurdu babam. Fakat onlar anlamıyorlardl. Babamda mecliste Ingilizlerle Ingilizce, Araplarla Arapça olarak tartışırdl. Ama Bedevi dediğimiz gerçekten çok ayrı bir şeydi. Kendisi kendi kültürüyle bile ilgili değil. Ha ama kızamazsınız çölün ortasında çok ayrı bir hayat onlarınkisi(...)" (Üstün 2020, 77).

Sadullah Koloğlu, Libya'nın içinde bulunduğu zorlu şartlara ve İngilizlerin bölgedeki nüfuzuna rağmen başbakanlığı döneminde Libya'nın bağımsızlığını tesis etmek için mücadele vermiştir. O dönem Şeyh İdris Senusî sadece Bingazi bölgesine hâkimdir. Libya üç parça olup Trablus ve Fizan da vardır. Ancak oralar ABD ve Fransa'nın kontrolü altındadır. Sadullah Koloğlu bir yandan bu üç bölgenin birleşmesi mücadelesini vermiş, bir yandan da Bingazi üzerindeki hâkimiyetlerini yitirmek istemeyen İngilizlere karşı direnmiştir. Nihayetinde 1952 yılı başlarında Libya bağımsızlığını kazanmış ve Şeyh İdris Senusî de Kral İdris olmuştur. Türkiye Cumhuriyeti vatandaşı olduğu için Sadullah Koloğlu'nun başbakanlığı da sona ermiştir. 28 Mayıs 1952 tarihinde ülkesine dönmeye hazırlanırken de vefat etmiştir (Orhan Koloğlu, “Libya'nın İlk Başbakanı Türk'tü: Babam Sadullah Koloğlu”, 22 Şubat 2016). Neticede Sadullah Koloğlu, görev aldığı bu kısa süre zarfinda, doğup büyüdüğü topraklara önemli hizmetlerde bulunmuştur. 


\section{Sonuç}

Osmanlı Kuzey Afrika'sının önemli bir bölümünü teşkil eden Trablusgarp ve Bingazi, aynı zamanda Osmanlı'nın Afrika'da kaybettiği son toprak parçalarıdır. Nitekim 1881'de Tunus Fransızlar, 1882'de de Afrika'nın en önemli toprak parçası olan Mısır İngilizler tarafından işgal edilmiştir. Dolayısıyla Afrika'daki son kale hüviyetinde olan Trablusgarp ve Bingazi’ye özel bir önem verilmiştir. Burası, siyasi, ekonomik, askeri açılardan önemli özelliklere sahiptir. İskenderun, İzmir, İstanbul, Beyrut gibi limanlar sayesinde Avrupa ile Asya arasındaki bağlantıyı sağlamıştır. Önemli limanlara ve ticaret yollarına sahiptir. Afrika'nın kuzey, batı ve merkezinden gelen binlerce hacı için de geçiş ve toplanma alanıdır. Dolayısıyla pek çok özelliği içinde barındıran bu coğrafya, devletin kaybetmemek için sonuna kadar mücadele edeceği bir yer olmuştur.

Osmanlı Hükümeti, bölgeden gelen raporlar doğrultusunda önlemler alarak bölgede kalıcı olmaya çalışmıştır. Bu doğrultuda nüfusu, ekonomiyi, askeri yapıyı güçlendirmek için yerel idareyle birlikte çeşitli imar ve iskân faaliyetleri yürütmüştür. Hamidiye alayları oluşturulması, limanlar, yollar yapılması, çeşitli kurumların ıslah edilmesi bunlardan bazılarıdır. Diğer taraftan, bölgede işlenmeye hazır geniş araziler olmasına rağmen, "yetenekli, bilgili insan gücü” eksikliğinin olmasından dolayı ilerleme sağlanamadığı görülmüş ve bu eksikliğin giderilmesi halinde ise farklı açılardan pek çok fayda sağlanacağı bölgeden gönderilen raporlarda ifade edilmiştir. Bu konuya çözüm olarak da son dönemde Anadolu'ya akın akın gelen göçmenlerin değerlendirilmesi düşünülmüştür. Hükümet, bölgenin aktif hale gelmesi ve üretime açılması için göçmenlerin iskânını bir firsat olarak görmüş ve bunu değerlendirmek için çalışmalarını başlatmıştır. Böylelikle hem bölge hem de ülke menfaatine fayda sağlanması amaçlanmıştır.

$\mathrm{Bu}$ amaç doğrultusunda Kırım, Rumeli, Kafkas, Girit göçmenleri bölgeye yerleştirilmek istenmiştir. Fakat Kırım, Kafkas ve Rumeli göçmenlerinin sevk ve iskânında birtakım sorunlarla karşılaşılmış ve onların bölgeye yerleştirilmesi mümkün olmamıştır. Bunlardan sadece Girit göçmenlerinin bölgeye sevki ve kısmen de olsa yerleşimi söz konusu olmuştur. Bütün zorlu şartlara, uyum problemlerine rağmen bölgede tutunmayı başaran az sayıdaki göçmen grubu, Bingazi coğrafyasında, sosyal ve ekonomik açıdan birtakım farklılıkları ortaya çıkarmışlardır. Dünyanın geri kalmış bir bölgesinde belli bir gelişmeye ön ayak olmuşlardır.

Göçmenler, yaşam şekli, konuşma, giyim kuşam alanında olduğu gibi ekonomik uğraş alanında da bölgede etkili olmuşlardır. Yerli ahalisi çoğunlukla göçebe olan bir bölgede, yerleşik hayatı tesis etmişler ve bu anlamda örnek olmuşlardır. Barınma alanlarının eksik olduğu iskân mahallerinde, yeni meskenler inşa edilmesiyle gelecekte oluşacak olan şehirlerin çekirdeğini oluşturmuşlardır. Kısa süre zarfında özellikle tarım alanında etkili olarak bağ, bahçe gibi alanların işlenmesine, çeşitli ürünlerin yetiştirilmesine katkı sağlamışlardır. Aynı zamanda bölgedeki Osmanlı askeri birlikleri içerisinde yer almışlar ve Osmanlı otoritesini tehdit eden unsurlara karşı verilen mücadeleye destek olmuşlardır. Kısacası göçmenlerin hem yaşam şekilleriyle hem de mesleki uğraşlarıyla bölgenin sosyokültürel ve ekonomik hayatına canlılık ve yenilik getirdiklerini ve bölgede yerel bir güvenlik birimini teşkil ettiklerini söylemek mümkündür.

Tabi ki burada verilen örnekler 1şı̆̆ında göçmenlerin bölge ekonomisine katkılarını tamamıla tayin etmek zordur. Bunun için gerekli olan istatistiki veriler mevcut değildir. $\mathrm{Bu}$ çalışmada, farklı bir bölgeden göç eden ve geldikleri bölgede belli bir etki yaratan göçmenlerin mesleki deneyimlerinin, "kuvveden fiile geçirme amacına yönelik" meydana getirdiği hareketlilik vurgulanmak istenmiştir. Bir başka deyişle, Osmanlı Hükümeti'nin başlangıçta hedeflediği "yerli halkın medenileştirilmesi" kapsamında göçmenlerin deneyimlerinden 
faydalanma gayretini ve bunun sosyal, kültürel ve ekonomik sonuçlarını örnekleriyle ortaya koymak amaçlanmıştır. Nitekim elde edilen veriler gösteriyor ki bu aileler, Osmanlı hâkimiyetinin sona ermesinden sonra da zorlu şartlara rağmen bölgede yaşamaya devam etmişler ve Osmanlı mirasının yaşayan unsurları olmuşlardır. Nitekim bugün Libya ile olan tarihi bağlar, ülke nüfusu içinde yer alan Anadolu, Girit kökenli Türklerin varlığı sayesinde devam etmektedir. Bu tarihi miras, Libya'yı Türkiye'nin tarihi derinliğinde önemli bir noktaya oturtmaktadır.

Libya topraklarının savunulması için Enver Paşa ve Türkiye Cumhuriyeti'nin kurucusu Mustafa Kemal Atatürk gibi dönemin en genç subayları, o güne kadar hiç görev yapmadıkları bir cepheye koşmuşlardır. İki bin kilometrelik bir sahil hattı üzerinde bin veya altı bin Osmanlı askerinin, yerli halkla işbirliği yaparak yüz bin kişilik İtalyan ordusuna karşı sürdürdükleri mücadele dikkate değerdir. Ali Fethi Okyar, burada verilen mücadeleyle ilgili olarak, “...Trablusgarp’taki vatanseverlik ve yiğitlik dünyaya anlatılsa idi, Türklügüun her şeyini kaybettiği düşüncesinin hâkim olduğu o günlerde, dünyanın gözü önünde itibarımız yerini almakla kalmaz, hayranlı uyandirırdlk. Trablusgarp bugünkü neslin bilmesi gereken vatanseverlik destanıdır." (Balkaya 2005, 20) demiştir. Burada verilen mücadele, Osmanlı'nın Afrika sahillerinde yaptığı son savaş olmakla birlikte her iki ülkenin ortak tarihinde büyük bir dostluğun mevcut olduğunu göstermesi bakımından da önemlidir. Ayrıca, Osmanlı Devleti'nin son dönemde Trablusgarp ve Bingazi'de var olma mücadelesi, bugün Türkiye Cumhuriyeti'nin Libya'da yaşanan gelişmelere duyarsız kalmaması ve etkin görev üstelenmeye çalışmasıyla paralellik göstermektedir.

\section{BİBLİYOGRAFYA}

Adiyeke A. N. \& Adiyeke N. 2006, "Olive Production in Crete in 19th Century". Bulgarian Historical Review-Revue Bulgare d'Histoire 3-4, 155-167.

Adıyeke A. N. \& Adıyeke N. 2021, Osmanlı Dönemi Kısa Girit Tarihi. İstanbul.

Ağanoğlu H. Y. 2012, Osmanlı'dan Cumhuriyet'e Balkanlar'in Makûs Talihi Gö̧̧. İstanbul.

Akbulat E. F. 2018, "Suriye Çerkesleri: Suriye İç Savaşı ve Mülteci Krizine Suriye Çerkesleri Perspektifinden Bir Bakış". Ylldız Sosyal Bilimler Enstitüsü Dergisi II/2, 1-17.

Akkayan T. 1979, Göç ve Değişme. İstanbul Üniversitesi Edebiyat Fakültesi, İstanbul.

Arslan H. 2001, 16. Yüzyll Osmanlı Toplumunda Yönetim, Nüfus, İskân, Göç ve Sürgün. Kaknüs Yayınları, İstanbul.

Astrakanaki A. 2014, "Libya: Selamsız Bandosu Gerçek Oldu”. Giritliler Gazetesi, Ortadoğu Özel Sayısı, Aralık, 8-9.

Avagyan A. 2004, Osmanlı İmparatorluğu ve Kemalist Türkiye'nin Devlet-iktidar Sisteminde Çerkesler, Çev. Ludmilla Denisenko. İstanbul.

Bahadır Y. 2008, Anadolu'ya Göçler Tarih-Toplum-Kimlik. Trabzon.

Balkaya İ. S. 2005, Ali Fethi Okyar (29 Nisan 1880-7 Mayıs 1943), Ankara.

Barkan Ö. L. (1942). "Osmanlı İmparatorluğunda Bir İskân ve Kolonizasyon Metodu Olarak Vakıflar ve Temlikler, I. İstila Devirlerinin Kolonizatör Türk Dervişleri ve Zaviyeler”. Vakıflar Dergisi II, 279386.

Barkan Ö. L. 1949-50, "Osmanlı İmparatorluğu'nda Bir İskân ve Kolonizasyon Metodu Olarak Sürgünler”. IÜIFM XI, 56-78.

Baykara T. 1999, "Bir Kelime-Istılah ve Zihniyet Olarak "Medeniyet”'in Türkiye'ye Girişi”. Osmanlılarda Medeniyet Kavramı ve On Dokuzuncu Yüzyıla Dair Araştırmalar. İzmir.

Benzabih H. A. 1982, “The Jabal al-Akhdar: A Half Century of Nomadic Livelihood”. Eds. E. G. H. Joffé \& K.S. McLachlan, Social and Economic Development of Libya. Cambridgeshire, UK, 196-97. 
Bergen L. 2012, “Medeniyet Ekseninde Kültür”. Hece-Medeniyet Özel Saylsl, 186/187/188, HaziranTemmuz-Ağustos, 33-64.

Berzeg N. 2006, Çerkesler Kafkas Sürgünü: Vatansız Bırakılan Bir Halk. İstanbul.

Beydilli K. 2016, "Trablusgarp Savaş1”. DİA. EK-2, 613-616.

Bostan İ. 2008, "Sâdık el-Müeyyed Paşa (1858-1911)". TDV İslam Ansiklopedisi XXXV, 399-400.

Çelik G. 1996, "Osmanlı Türkiye'sine XIX. Yüzyıl Sonlarında Yapılan Göçlerin Sosyo-Ekonomik Bakımdan Tahlili”. Tarih Boyunca Balkanlardan Kafkaslara Türk Dünyası Semineri Bildiriler. İstanbul, 121-122.

Çınar A. O. 2012, "Bingazi'de Tarımsal Kalkınma Amaçlı Göçmen İskânı (1851-1904)". Ístanbul Üniversitesi Yakın Dönem Türkiye Araştırmaları Dergisi 4, 19-52.

Çelik G. 1999, “Osmanlı Devleti’nin Nüfus ve İskân Politikası”. Divan, 1999/1 49-110.

Çiçek K. \& Saydam A. 1998, "Ferman ile Tebdil-i Mekân: Osmanlı Devleti’nin İskân Siyaseti”. Ed. Kemal Çiçek ve Abdullah Saydam, Kıbrıs'tan Kafkasya'ya Osmanlı Dünyasında Siyaset, Adalet ve Raiyyet. Trabzon, 1-42.

Çilliler Y. 2015, "Modern Milliyetçilik Kuramları Açısından 19. Yüzyıl Osmanlı İmparatorluğu Fikir Akımları". Akademik Incelemeler Dergisi X/2, 45-65.

Davutoğlu A. 2012, "Medeniyetler Arası Etkileşim ve Osmanlı Sentezi”. Haz.: Coşkun Çakır, Osmanlı Medeniyeti, Siyaset-iktisat-Sanat. İstanbul, 3-13.

Değer M. 1998, Dr. Hüseyin Hüsnü Bey'in Not Defterinden Trablusgarp Savaşı. İstanbul.

Deringil S. 1991, "19. Yüzyılda Osmanlı İmparatorluğu’nda Göç Olgusu Üzerine Bazı Düşünceler”. IÜEF Tarih Araştırma Merkezi-Prof. Bekir Kütükoğlu'na Armağan'dan Ayrı Basım. İstanbul, 435442.

Dirim H. K. 1956, “Trablus Harbinde Derne Cephesi Sihhi Hizmetleri”. Dirim Aylık Tip Gazetesi 5-6, 153-157.

Doğru H. 1999, “Rumeli’de Fetih ve İskân Siyaseti”. Türkler Ansiklopedisi IX, 165-176.

Erkan S. 1996, Kırım ve Kafkasya Göçleri (1878-1908). Karadeniz Teknik Üniversitesi Kafkasya ve Orta Asya Ülkeleri Uygulama ve Araştırma Merkezi, Trabzon.

Ertuna H. 1981, Türk Silahlı Kuvvetleri Tarihi Osmanlı Devri Osmanlı-Italyan Harbi (1911-1912). Ankara.

Gall M. F. L. 1986, Pashas, Bedouin and Notables: Ottoman Administration in Tripoli and Benghazi, 1881-1902. PhD diss, Princeton University.

Göç Terimleri Sözlüğ̈̈. 2009. Uluslararası Göç Örgütü, İsviçre.

Gökaçtı M. A. 2010, Nüfus Mübadelesi: Kayıp bir Kuşağın Hikâyesi. İstanbul.

Gökbilgin M. T. 1977, Osmanlı Müesseseleri Teşkilatı ve Medeniyeti Tarihine Genel Bakış. İstanbul.

Gökbunar A. R. 2004, “19. ve 20. Yüzyıllarda Yaşanan Göçlerin Türk Maliye Tarihi Açısından Analizi”. Gazi Üniversitesi İktisadi ve İdari Bilimler Fakültesi Dergisi 6/3 231-252.

Gregory J. W. 1916, "Cyrenaica”. The Geographical Journal 47/5, 321-342.

Güran T. 2014, 19. Yüzyıl Osmanlı Tarımı Üzerine Araştırmalar. İstanbul.

Güran T. 2017, Resmî İstatistiklere Göre Osmanlı Toplum ve Ekonomisi. İstanbul.

Hadzı1ossıf C. 2018, “Zeytin ve Zeytinyağının Tarihselliği”. Zeytinin Akdeniz'deki Yolculuğu Konferans Bildirileri. İzmir, 96-105.

Halaçoğlu Y. 1999, "Kolonizasyon ve Şenlendirme”. Osmanlı IV, 581-586.

Hamed-Troyansky V. 2017, "Circassian Refugees and the Making of Amman, 1878-1914", International Journal of Middle East Studies 49/4, 605-23.

Hasluck F. W. 2003, Bektaşilik Incelemeleri. Çev. Ragıb Hulûsî, Haz. Mehmet Kanar. İstanbul.

Hülagü M. 2008, Bir Umudun İnşası Hicaz Demiryolu. İzmir.

İlhan S. 1990, Atatürk ve Askerlik -Düşünce ve Uygulamalart-. Atatürk Kültür, Dil ve Tarih Yüksek Kurumu Atatürk Araştırma Merkezi Yayınları, Ankara.

İnalc1k H. 1996, Osmanlı Imparatorluğu, Toplum ve Ekonomi. İstanbul.

İpek N. 1996, “Göçmen Köylerine Dair". Tarih ve Toplum 25/150, 15-16. 
İpek N. 2014, "Kaynakların Dilinde Göç Kavramı”. Karadeniz İncelemeleri Dergisi 9/17, Güz 9-20.

İpek N. 2013, “Osmanlı Devleti'nin Göç ve İskân Politikaları”. Ed. N. İpek \& M. Taştemir, Osmanlı'da İskân ve Gö̧c. Eskişehir.

İpek N. 2006, Imparatorluktan Ulus Devlete Göçler. Trabzon.

İpek N. 1999, Rumeli'den Anadolu'ya Türk Göçleri (1877-1890). Ankara.

İplikçi A. E. \& Bakır G. 2018, "Klazomenai Zeytinyağı İşliği”. Zeytinin Akdeniz'deki Yolculuğu Konferans Bildirileri. İzmir, 14-36.

Kafesoğlu İ. 1989, Türk Milli Kültürü, İstanbul.

Kara M. 2008, Girit Kandiye'de Müslüman Cemaati: 1913-1923. İstanbul.

Karaçavuş A. 2015, “Temeddünden Medeniyete (Civilisation): Osmanlı'nın İnsan Toplum ve Devlet Anlayışının Değişimi Üzerine Bir Deneme”. OTAM, 37/Bahar, 87-180.

Karasapan C. T. 1960, Libya (Trablusgarp, Bingazi ve Fizan). Ankara.

Karpat K. H. 2014, Osmanlı Modernleşmesi: Toplum, Kurumsal Değişim ve Nüfus. Çev. Ceren Elitez. İstanbul.

Karpat K. H. 2010a, Osmanlı Nüfusu (1830-1914) Demografik ve Sosyal Özellikleri, (Çev. Bahar Tirnakçı), Timaş Yayınları, İstanbul.

Karpat K. H. 2010b, Osmanlı'dan Günümüze Etnik Yapılanma ve Göçler. Çev. Bahar Tırnakçı. İstanbul.

Kavas A. 2002, “Afrika'da Türkler'in Hâkimiyeti ve Kurdukları Devletler”. Yeni Türkiye Dergisi Türkler Özel Saylsı IX, 575-588.

Kavas A. 2003, "Türkiye'de Osmanlı Afrikası Araştırmaları". Türkiye Araştırmaları Literatür Dergisi $\mathrm{I} / 2,513-528$.

Kavas A. 2005, "Türkiye-Libya İlişkileri”. TASAM Stratejik Öngörü 6, 46-56.

Kavas A. 2013, Osmanll-Afrika İlişkileri. İstanbul.

Kaya A. \& Erdoğan, M. M. 2015, “Giriş Kısmı”. Türkiye'nin Göç Tarihi, 14. Yüzyıldan 21. Yüzylla Türkiye’ye Göçler. Der.: M. Murat Erdoğan \& Ayhan Kaya. İstanbul Bilgi Üniversitesi Yayınları, İstanbul.

Kaynar R. 1985, Mustafa Reşit Paşa ve Tanzîmat. Ankara.

Kazıc1 Z. 2016, Unutulan Medeniyet Osmanl. İstanbul.

Kızılkaya O. \& Akay T. 2013, "Kafkasya Muhacirlerinin Suriye Vilayetine İskânı ve Karşılaşılan Zorluklar". Turkish Studies 8/2, 137-152.

Kocacık F. 1980, "Balkanlar'dan Anadolu'ya Yönelik Göçler (1878-1890)". Osmanlı Araştırmaları 1/1, 137-190.

Koloğlu O. 2016, “Libya'nın ilk başbakanı Türk'tü: Babam Sadullah Koloğlu”. http://www.turksolu.com.tr/libyanin-ilk-basbakani-turktu-babam-sadullah-kologlu/, 22 Şubat 2016. (Erişim: 22.6.2016).

Koloğlu O. 2001, Arap Kaymakam, İstanbul.

Koloğlu O. 2003, Osmanll Meclislerinde Libya ve Libyalllar. İstanbul.

Kurşun Z. 2013, “Trablusgarp Savaşı'nın Osmanlı Devleti'nin Mukadderatındaki Yeri”. Haz. Prof. Dr. Mehmet Ersan \& Dr. Nuri Karakaş, Osmanlı Devleti'nin Dağılma Sürecinde Trablusgarp ve Balkan Savaşları, 16-18 Mayıs/İzmir Bildiriler. Ankara, 3-17.

Kutluer İ. 1998, "Medeniyet”. DIA. XXVIII, 296-297.

Kürşat İ. 1999, "Girid Olaylar1-1897 Türk-Yunan Savaşı”. Belgelerle Türk Tarihi Dergisi 24, 68-76.

Lewis B. 2007, Modern Türkiye'nin Doğuşu. Çev. Metin Kıratlı. Ankara.

Lorenz F. W. 2021, "The "Second Egypt": Cretan Refugees, Agricultural Development, and Frontier Expansion in Ottoman Cyrenaica, 1897-1904". International Journal of Middle East Studies 53, 89105.

McCarthy J. 2012, Ölüm ve Sürgün: Osmanlı Müslümanlarının Etnik Klyımı(1821-1922). Çev. Fatma Sarıkaya. Ankara.

McCharty J. 1998, Müslümanlar ve Azınliklar. İstanbul. 
Mehmet Ziya. 2009, Bursa'dan Konya'ya Seyahat. Haz. Mehmet Fatih Birgül \& Levent Ali Çanaklı. Ankara.

Menekşe M. 2018, Girit Müslümanlarının Zorunlu Göçü: Sevk ve İskân (1897-1913). Muğla Sttk1 Koçman Üniversitesi Sosyal Bilimler Enstitüsü Tarih Anabilim Dalı Basılmamış Doktora Tezi. Muğla.

Mitçotakis Z. 1992, O Dimosiografos Elefterios Venizelos-Sta Hronia tis Kritis, 1887-1910. Atina.

Ortaylı İ. 2006, "Genel Göç Olgusu". Uluslararası Göç Sempozyumu Bildiriler, 8-11 Aralık 2005. İstanbul, 19-22.

Osmanlı Medeniyeti, Siyaset-İktisat-Sanat. 2012, "Sunuş". Haz.: Coşkun Çakır. İstanbul.

Özata M. 2015, Atatürk ve Hekimler. İstanbul.

Pakalın M. Z. 1971, Osmanlı Tarih Deyimleri ve Terimleri Sözlüğ̈̈ II, İstanbul.

Parvus Efendi. 1977, Türkiye'nin Mali Tutsaklı̆̆ı. Çev: Muammer Sencer. İstanbul.

Planhol X. D. 1975, "Elements Ottomans Dans la Physionomie Geographique de la Cyrenaique", Bulletin de I'Association des Geographes Français, N429-430, 52e année, Novembre-Décembre. 353-363.

Popovic A. 1995, Balkanlar'da İslam. Türkçesi: Komisyon, İstanbul.

Quataert D. 2000, “19. Yüzyıla Genel Bakış: Islahatlar Devri 1812-1914”. Eds. Halil İnalcık \& Donald Quataert, Osmanlı İmparatorluğunun Ekonomik ve Sosyal Tarihi, Cilt: II. İstanbul, 887-1051.

Sâdık el-Müeyyed. 2018, Afrika Sahra-yı Kebiri'nde Seyahat. İstanbul.

Sarıbal İ. 2018, Osmanl Devleti'nde Muhaceret, İskân ve Entegrasyon: Bursa Sancağı Örneği (18451908). İstanbul.

Saydam A. 2010, Kırım ve Kafkas Göçleri (1856-1876). Ankara.

Şakar H. Y. 2019, Mâzimdeki Bodrum ve Bodrumlular. Haz.: M. Kocair \& Cezmi Çoban. Bodrum.

Taş A. E. 2016, Osmanlı Garp Ocaklarından Trablusgarp Eyaleti: Karamanlılar Dönemi (1711-1835). İstanbul Üniversitesi Sosyal Bilimler Enstitüsü İslam Tarihi ve Sanatları Anabilim Dalı Basılmamış Doktora Tezi. İstanbul.

Tekeli İ. 1990, “Osmanlı İmparatorluğu'ndan Günümüze Nüfusun Zorunlu Yer Değiştirmesi ve İskân Sorunu". Toplum ve Bilim 50, 49-71.

Tekeli İ. 1998, “Türkiye'de Cumhuriyet Döneminde Kentsel Gelişme ve Kent Planlaması”. Ed. Y. Sey, 75 Yllda Değişen Kent ve Mimarlık, Bilanço: 98. İstanbul, 1-24.

Tekeli İ. 2013, Göç ve Ötesi. İstanbul.

Umar Ö. O. 2004, Osmanlı Yönetimi ve Fransız Manda İdaresi Altında Suriye (1908-1938). Atatürk Araştırma Merkezi, Ankara.

Ünal M. A. 2002, “Osmanlı Devri Türk Kültür ve Medeniyetinin Temel Özellikleri”. Türkler IX, 54-59.

Ünal M. A. 2010, Osmanlı Müesseseleri Tarihi. Isparta.

Üstün A. 2020, Türkiye-Libya İlişskileri (1951-2011). Bursa Uludağ Üniversitesi Sosyal Bilimler Enstitüsü Tarih Anabilim Dalı Yayımlanmamış Yüksek Lisans Tezi. Bursa.

Yalçın C. 2004, Gö̧̧ Sosyolojisi. Ankara.

Yılmaz M. 1999, “XIX. Yüzyılda Osmanlı Devleti’nin Muhaciri İskân Politikası”. Osmanlı IV, 587-602.

\section{Kaynak Eserler, Resmi ve Süreli Yayınlar}

Ali Tevfik. 1318, Memâlik-i Osmaniyye Coğrafyası, Coğrafya-yı Umumiyye, Cilt: III. İstanbul.

Ali \& Ahmed Nuri. 1301, Afrika-i Osmanîden Trablusgarb ve Bingazi ve Fizan Kit'alarına Dair Coğrafì ve İstatistikî ve Tarihî ve Siyasî ve Askerî Malumâtı Havî Bir Risale. İ.Ü. Kütüphanesi, TY. No: 5002.

Arşiv Belgelerine Göre Balkanlar'da ve Anadolu'da Yunan Mezâlimi-I: Balkanlar'da Yunan Mezalimi. 1995, T.C. Devlet Arşivleri Genel Müdürlüğü Osmanlı Arşivi Daire Başkanlığı, Yayın Nu: 22, Ankara.

Binbaşı Abdülvahid. 2020, II. Abdülhamid Zamanında Bir Osmanlı Binbaşısının Gözünden Libya. Haz.: S. Kıziltoprak \& Ş. Deniz. İstanbul.

Dlş Türkler (Belgeler). 1969, T.C. Dışişleri Bakanlığı AZEM Dairesi, Ankara. 
Domingo Badia y Leblich (Ali Bey). (1816). Travels of Ali Bey in Morocco, Tripoli, Cyprus, Egypt, Arabia, Syria and Turkey Between The Years 1803 and 1807, Volume: I. London.

Hogarth D. G. 1904, "A Visit to Cyrene”. Times, 16 Ağustos 1904.

Meclis-i Mebusan Zabıt Ceridesi. 24 Mayıs 1326 (6 Haziran 1910, Pazartesi) Oturumu.

Muhammed el Usta. 1983, Verakât Matviyye. Trablusgarp.

Slousch N. 1908, "Les Cretois en Cyrenaique". Revue Du Monde Musulman VI/10, 151-153.

Osmanlı Belgelerinde Kafkas Göçleri. 2012, Cilt: I, T.C. Devlet Arşivleri Genel Müdürlüğü Osmanlı Arşivi Daire Başkanlığı Yayın Nu: 121. İstanbul.

Ömer Subhi Bey. 2007, Hüdavendigar Vilayetinde Bir Hafta Seyahat. Haz.: N. Özdemir. İstanbul.

Ömer Subhi Bey. 1307, Trablusgarb ve Bingazi İle Sahra-yl Kebir ve Sudan Merkezi. İstanbul Üniversitesi Kütüphanesi, TY. No: 4261. İstanbul.

“Trablusgarp'ın Müslümanlarca Ehemmiyeti ve İtalya’nın Afrika'da Müslümanları Boğmak Emeli”. Sebîlü'r-reşâd, Adet: 186-4, 9 Rebiülahir 1330/28 Mart 1912.

\section{Arşiv Belgeleri}

BCA, Fon No: 30-18-1-2, Kutu No: 121, Dosya No: 101, Sira No: 20, s. 1, 23 Ocak 1950. BOA, A. MKT. MHM., Dosya No: 506, Gömlek No: 11, 14 Eylül 1315/26 Eylül 1899.

BOA, A. MKT. MHM., Dosya No: 506, Gömlek No: 11, 15 Teşrinievvel 1315/27 Ekim 1899.

BOA, A. MKT. MHM., Dosya No: 506, Gömlek No: 11, 30 Mart 1318/12 Nisan 1902.

BOA, A. MKT. MHM., Dosya No: 506, Gömlek No: 11, 5 Şubat 1315/17 Şubat 1900.

BOA, DH. MHC., Dosya No: 16, Gömlek No: 22, 10 Şubat 1314/22 Şubat 1899.

BOA, DH. MHC., Dosya No: 19, Gömlek No: 23, Lef: 1-1, 8 Ağustos 1315/20 Ağustos 1899.

BOA, DH. MHC., Dosya No: 27, Gömlek No: 59, Lef: 3-1, 27 Mayıs 1316/10 Haziran 1900.

BOA, DH. MHC., Dosya No: 42, Gömlek No: 6, Lef: 11-2, 4 Mart 1316/17 Mart 1900.

BOA, DH. MHC., Dosya No: 48, Gömlek No: 71, Lef: 4-1, 11 Temmuz 1317/24 Temmuz 1901.

BOA, DH. MHC., Dosya No: 48, Gömlek No: 71, Lef: 8-2, 2 Nisan 1318/15 Nisan 1902.

BOA, DH. MHC., Dosya No: 48, Gömlek No: 71, Lef: 9-1, 30 Mart 1318/12 Nisan 1902.

BOA, DH. MKT. PRK., Dosya No: 2197, Gömlek No: 137, 24 Temmuz 1315/5 Ağustos 1899.

BOA, DH. MKT., Dosya No: 2664, Gömlek No: 40, 6 Teşrinisani 1324/19 Kasım 1908.

BOA, HR. İD., Dosya No: 16, Gömlek No: 12, 9 Teşrinisani 1307/21 Kasım 1891.

BOA, İ. DH., Dosya No: 1244, Gömlek No: 97479, 10 safer 1309/15 Eylül 1891.

BOA, İ. MTZ. GR., Dosya No: 33, Gömlek No: 1363, 30 Mayıs 1315/2 Haziran 1899.

BOA, MVL., Dosya No: 762, Gömlek No: 37, 27 Zilkade 1278/26 Mayıs 1862.

BOA, MVL., Dosya No: 762, Gömlek No: 37, Gurre-i Zilkade 1278/Mayıs 1862.

BOA, ŞD. DH., Dosya No: 2325, Gömlek No: 32, 17 Cemaziyülevvel 1297/27 Nisan 1880.

BOA, Y. MTV., Dosya No: 53, Gömlek No: 71, 12 Ağustos 1307/24 Ağustos 1891.

BOA, Y. PRK. A., Dosya No: 6, Gömlek No: 78, 2 Safer 1309/7 Eylül 1891.

BOA, Y. PRK. AZJ., Dosya No: 19, Gömlek No: 22, 16 Şevval 1308/25 Mayıs 1891.

BOA, Y. PRK. KOM., Dosya No: 8, Gömlek No: 4, 3 Ağustos 1307/ 16 Ağustos 1891.

TNA, PRO, FO, 101/89, 18 Eylül 1899. 